\title{
Interbank Contagion at Work: Evidence from a Natural Experiment
}

\author{
Rajkamal Iyer and José-Luis Peydró ${ }^{\dagger}$ \\ June 2009 \\ (Forthcoming Review of Financial Studies)
}

\begin{abstract}
This paper tests financial contagion due to interbank linkages. For identification we exploit an idiosyncratic, sudden shock caused by a large-bank failure in conjunction with detailed data on interbank exposures. First, we find robust evidence that higher interbank exposure to the failed bank leads to large deposit withdrawals. Second, the magnitude of contagion is higher for banks with weaker fundamentals. Third, interbank linkages among surviving banks further propagate the shock. Finally, we find results suggesting that there are real economic effects. These results suggest that interbank linkages act as an important channel of contagion and hold important policy implications.
\end{abstract}

\footnotetext{
${ }^{\dagger}$ University of Amsterdam, Department of Finance, Roetersstraat 11, 1018 WB, Amsterdam, E-mail: R.J.Iyer@uva.nl; European Central Bank, Kaiserstrasse 29, D-60311, Frankfurt am Main, Germany. E-mail: jose-luis.peydro-alcalde@ecb.europa.eu. We would like to thank the Reserve Bank of India and the Gujarat Urban Co-operative Banking Federation for their help through the study. We would especially like to thank Dr. R. B. Barman and Mr. Gokul Parikh. We are extremely grateful to Xavier Vives for all his help and guidance. We would also like to thank for helpful comments and suggestions the editor and two anonymous referees, Viral Acharya, Franklin Allen, Paolo Angelini, José Manuel Campa, Antonio Ciccone, Amil Dasgupta, Mihir Desai, Bernard Dumas, Xavier Freixas, Reint Gropp, Philipp Hartmann, Ed Kane, Paul Kupiec, Alfred Lehar, Joseph Mason, Sendhil Mullainathan, Erland Nier, Steven Ongena, Elias Papaioannou, Urs Peyer, Manju Puri, Rafael Repullo, Antony Saunders, Marti Subramanyam, Martin Summer, Christian Upper and seminar participants at the Bank of Spain, Cass Business School, ECB, HKMA, HKUST, IESE, Indian Institute of Management at Ahmedabad, INSEAD, MIT, NYU Stern, UvA, and also the 4th CGFS Joint Central Bank Research Conference on Risk Measurement and Systemic Risk, the 5th Annual Banking Research Conference at FDIC, the Financial Intermediation Research Society meetings at Shanghai and the European Finance Association Meetings at Zurich. All errors are our responsibility and the opinions expressed in this paper are those of the authors and do not reflect the views of the European Central Bank or the Eurosystem.
} 
"Since the onset of the financial turmoil, increased uncertainty, reflected particularly in counterparty risk, has led banks to hoard liquidity. This has resulted in a significant decline of trading in the interbank money markets."

Jean-Claude Trichet, President of the European Central Bank, December 2008

\section{Introduction}

The current global financial crisis has once again highlighted that the interbank markets can act like a double-edged sword. On the one hand, interbank markets play a very important role for the provision of liquidity among banks. On the other hand, if a bank fails, the interbank market could transmit the shock (interbank contagion). ${ }^{1}$ As a consequence, the fear of interbank contagion may reduce interbank lending and, in turn, impair liquidity provision among banks. The recent drying up of liquidity in the interbank markets in the wake of the heightened counterparty default risk in the current financial crisis aptly reflects this fear. In addition, if interbank contagion materializes, a banking crisis is even more likely. Hence, given the economic importance of interbank markets and the large economic costs associated with banking crises (Friedman and Schwartz 1963; Bernanke 1983, Ongena et al. 2003, Calomiris and Mason 2003a, Dell'Ariccia et al. 2005, Gan 2007), it is of utmost importance to understand the role of the interbank market in financial contagion. In this paper, we empirically address the role of interbank exposures as a channel of financial contagion.

After the failure of a bank, the risk of financial contagion due to interbank linkages is primarily due to a loss in value for creditor banks that hold interbank claims in the failed bank (henceforth, exposure). Furthermore, the loss for creditor banks may increase over and above the exposure in the failed bank due to the (over)reaction of the creditor banks' depositors (both retail and wholesale depositors). In consequence, the degree of contagion from the failed bank to another bank should depend on its level of interbank exposure to the failed bank (Allen and Gale 2000). Unfortunately, despite the importance of the question, there are no empirical papers that test for financial contagion due to interbank linkages.

\footnotetext{
${ }^{1}$ There is contagion if the failure of a bank causes a significant negative externality to other banks (e.g., high levels of deposit withdrawals). For a very similar definition of contagion, see Kaminsky and Reinhart (2000). Interbank contagion is the part of contagion due to interbank linkages. For an excellent survey on bank contagion, see Kaufman (1994). For a survey on systemic risk in banking, see Bandt et al. (2009); and for a survey on financial crisis, see Allen and Gale (2007).
} 
A major problem in testing for financial contagion due to interbank linkages is the lack of detailed data on interbank linkages during a crisis time. Most often it is almost impossible to get information on the interbank exposures of banks. In consequence, at the time of the failure of a bank, it is very difficult to map the transmission of the shock due to interbank linkages. Apart from the lack of data on interbank exposures, another major problem to test for contagion is the dearth of large-bank failures, which implies a lack of events for empirical studies. One of the main reasons for lack of large-bank failures is that regulators generally resort to bailouts whenever there is a large-bank failure that poses the risk of contagion due to interbank linkages. For example, after studying more than 100 bank failures, Goodhart and Schoenmaker (1995) conclude: "It has been revealed preference of the monetary authorities in all developed countries to rescue those large banks whose failure might lead to a contagious, systemic failure.” This view also comes forth in a speech by the Chairman of the Federal Reserve, Ben Bernanke, in October 2008 in the context of the current financial crisis. He asserted, "The Federal Reserve will work closely and actively with the Treasury and other authorities to minimize systemic risk." Another major hurdle for identifying the importance of interbank linkages as a channel of contagion is that very often the failure of the first bank is not exogenous to the general economic conditions, in turn, making it difficult to disentangle the contagion effects and its sources.

In this paper, we overcome these hurdles by exploiting: (i) an event of sudden failure of a large cooperative bank in India - the bank failed due to fraud and was not bailed out (there was no other fraud in other banks and the economy was performing well); (ii) a unique dataset that allows us to identify interbank exposures at the time of the bank failure. Our dataset provides us with detailed information on the interbank exposures of banks in the system with the failed bank. We also have information on the interbank linkages of banks among themselves apart from the exposures with the failed bank. This provides us with an ideal platform - a natural experiment - to test the hypothesis of financial contagion due to interbank linkages and also to study its implications. More specifically, we address the following questions: Does higher interbank exposure (credit outstanding as a fraction of total assets) to the failed bank increase deposit withdrawals? What factors affect the magnitude of contagion? I.e., do stronger bank fundamentals reduce the magnitude of contagion? Do interbank linkages among surviving banks (apart from 
exposure to the failed bank) further propagate the shock? What are the real economic effects of interbank contagion?

The key finding is that higher interbank exposure to the failed bank generates larger deposit withdrawals. After controlling for bank fundamentals and local macroeconomic conditions, we find that banks with higher levels of exposure to the failed bank experience lower deposit growth. We also find that banks with weaker fundamentals experience lower deposit growth. While the effect of higher levels of exposure on deposit growth is negative, this does not necessarily imply that banks with higher levels of exposure suffer large deposit withdrawals as predicted by theories of financial contagion. To address this concern, we investigate whether banks with higher levels of exposure face a higher probability of large deposit withdrawals. ${ }^{2}$ We find that the probability of facing large deposit withdrawals increases by 34 percentage points if a bank has a high level of exposure. Thus, exposure has an economically significant effect on deposit withdrawals. Finally, through piece-wise linear regressions, we find that the impact of exposure on deposit withdrawals is greater for higher levels of exposure, thus suggesting a nonlinear effect of bank exposure on deposit withdrawals.

A potential concern in the interpretation of our findings is that exposure levels to the failed bank are voluntarily chosen by banks. To address this concern, we first check whether banks with higher exposure levels are ex ante different in terms of riskiness and profitability. We do not find any significant differences. Second, we check if exposure level is just a proxy for physical distance from the failed bank or for correspondent banking relationship with the failed bank. We find that, despite these controls, the level of exposure to the failed bank is significant in explaining deposit withdrawals. ${ }^{3}$ Third, we check whether exposure affects deposit withdrawals before the crisis. The idea being that one should not expect any significant effect in the period before the failure. The results support this intuition, thereby suggesting that deposit withdrawals are primarily a result of exposure to the failed bank and are not driven by some other omitted characteristics of the banks that are correlated with exposure. Finally, to further push on causality, we instrument for exposure using a variable that indicates whether a bank lends in the interbank market

\footnotetext{
${ }^{2}$ We define large deposit withdrawals as deposit withdrawals exceeding $12.75 \%$ of deposits. This, in turn, implies that $20 \%$ of banks in our sample suffer large deposit withdrawals. Our results are robust to other definitions of large deposit withdrawals.

${ }^{3}$ The effect exposure on deposit withdrawals could also be due to the regulator requiring banks with higher exposure to reduce their deposit rate, thereby creating difficulty in retaining deposits. However, we find that changes in the deposit rate paid by banks are not related to the level of exposure.
} 
excluding the lending to the failed bank. The economic intuition for the instrument is that banks that lend in general in the interbank market are also likely to have exposure to the failed bank and, lending in the interbank market (apart from the exposure to the failed bank) by itself should not be related to deposit withdrawals. We find that interbank lending is highly correlated with exposure (t-statistic in the first stage regression is 3.46); thus the instrument does not suffer from weak instrument concerns (Staiger and Stock 1997). More important, from the second-stage regression, the estimates suggest that the component of exposure to the failed bank predicted by the overall lending presence in the interbank market has a highly significant effect on the probability of facing large deposit withdrawals.

The previous set of results supports the key cross-sectional hypothesis derived from the theory that higher exposure to the failed bank implies more deposit runs. We then explore the further implications from interbank contagion. We first explore whether stronger bank fundamentals play a role in reducing the magnitude of contagion. Specifically, we find that the impact of exposure on deposit withdrawals is higher for banks (i) with lower level of capital, (ii) smaller in size, and (iii) classified as weak by the regulator. These results suggest that the magnitude of contagion is lower for banks with stronger fundamentals. This, in turn, implies that weaker fundamentals of the banking system amplify the magnitude of interbank contagion.

In addition, to understand whether interbank markets further aggravate or dampen the magnitude of contagion, we also investigate the effect of other outstanding interbank linkages among surviving banks (apart from linkages with the failed bank) on deposit withdrawals. We find that the amount that banks lend in the interbank market (excluding exposure to the failed bank) does not affect deposit withdrawals. We also do not find any significant effect of the amount of borrowing in the interbank market on deposit withdrawals, which suggests that banks do not liquidate interbank deposits from the average bank. However, interestingly, we find that the impact of exposure on deposit withdrawals is larger for banks with higher amounts of interbank borrowing. Our analysis suggests that this finding is driven by banks liquidating their interbank deposits in banks with high level of exposure to the failed bank due to the fear of contagion.

Another important question we address is which class of depositors are withdrawing, thereby causing the interbank contagion. That is, given the previous results, is it only withdrawals by other banks that are causing interbank contagion? We find that even 
if we limit the analysis to banks with no interbank borrowings (i.e., banks that do not have other banks as depositors), exposure to the failed bank still has a significant effect on deposit withdrawals, thus suggesting that retail depositors also cause contagion by withdrawing deposits. More important, we find that, even for this set of banks, interbank contagion is larger if bank fundamentals are weak. In addition, we find that the impact of exposure on deposit withdrawals is larger for banks with higher numbers of depositors, which suggests that coordination problems among depositors are more important in banks with higher exposure (Rochet and Vives 2004, Goldstein and Pauzner 2005).

Although we find interbank contagion, it is important to study its real effects over and above the runs. We find that banks with higher exposure levels experience reductions in loan growth and profitability. However, to understand the real effects, it is important to investigate whether other banks increase their lending to compensate for this decline. Interestingly, we find that banks with lower exposure competitively gain deposits, and they gain especially in areas where the average level of exposure of other banks is high (these are the areas that are likely to face higher deposit withdrawals, and thus there is maximum opportunity to gain deposits competitively). However, this competitive gain in deposits does not translate into a corresponding increase in loans or profitability, which suggests that these banks hoard on the excess liquidity given the difficult banking environment they face. Given the borrowers' small size and bank dependence, the previous results suggest that there are real economic effects associated with interbank contagion.

Our paper contributes to the literature in several dimensions. The most important contribution of our paper is that we show evidence that suggests that interbank exposures transmit the shock of a bank failure. Using a natural experiment, we test the cross-sectional hypothesis that higher exposure to the failed bank implies more deposit withdrawals. The results that we find are consistent with theories of financial contagion due to interbank linkages (Allen and Gale 2000, Freixas et al. 2000, Dasgupta 2004, Brusco and Castiglionesi 2005). ${ }^{4}$ To the best of our knowledge, ours is the first paper that identifies whether interbank exposure to a failed bank transmits the shock. Existing studies on financial contagion due to interbank linkages have been limited to simulations due to lack of actual failure events. In addition, papers that test for contagion using an actual bank

\footnotetext{
${ }^{4}$ See also Flannery (1996), Rochet and Tirole (1996), Aghion et al. (2000), Cifuentes et al. (2005), Diamond and Rajan (2005), Iyer and Peydró (2005), and Leitner (2005).
} 
failure do not address the issue of interbank contagion due to lack of data on interbank linkages. Our paper bridges this void, in turn providing some directions for policy-making.

Our results also contribute to the literature that examines the role of depositors in banking crises. The finding that the magnitude of interbank contagion is higher for banks with weaker fundamentals suggests that bank fundamentals play an important role in depositor runs. These results are more in line with the theories of runs based on fundamentals (Chari and Jagannathan 1988, Gorton 1988, Jacklin and Bhattacharya 1988, Calomiris and Gorton 1991, Calomiris and Kahn 1991, Allen and Gale 1998) as against the pure panic-based theories of runs (Diamond and Dybvig 1983). In addition, our paper adds to the literature that explores the mechanisms to mitigate the impact of a banking crisis (Barth et al. 2004). Our results suggest that magnitude of contagion is lower if bank fundamentals are strong. Thus, mechanisms to improve the strength of the banking system can help in dampening a crisis. Our results also contribute to the empirical literature that examines depositor runs on banks (Saunders and Wilson 1996, Calomiris and Mason 1997, Schumacher 2000, Martinez Peria and Schmukler 2001) by showing that in addition to bank fundamentals, interbank linkages affect deposit withdrawals. Finally, our paper also contributes to the literature studying the costs of bank failures (Slovin et al. 1993). Our findings suggest that existing studies measuring bankruptcy costs associated with large bank failures understate the real effects as one needs to take into account deposit withdrawals at other banks due to exposure to the failed bank, especially given the associated real economic effects.

\subsection{Related Literature}

Most of the existing empirical studies on contagion focus primarily on measuring equity returns around large failures. They test whether all banks experience negative abnormal returns, or whether negative returns are limited to banks with similar characteristics to those of the failed banks. ${ }^{5}$ Aharony and Swary (1983) study the market reaction to the three biggest U.S. bank failures prior to that of Continental Illinois. Swary (1986) and Jayanti and Whyte (1996) examine the market effect of the failure of Continental Illinois. Aharony and Swary (1996) study the market reaction in the context of five large bank failures that

\footnotetext{
${ }^{5}$ In a similar spirit, Lang and Stulz (1992) investigate the contagion effects of bankruptcy announcements of firms.
} 
occurred in the southwest region of the United States during the mid-1980s. ${ }^{6}$ These papers find that surviving banks are most affected if they have portfolio characteristics similar to those of the failing institution. This, they argue, is evidence of information-based contagion. The most important feature that differentiates our paper from the literature cited above is that we use direct financial linkages among banks to test financial contagion due to interbank linkages.

There is an alternative stream of literature that studies the possibility of financial contagion due to interbank linkages via simulations. In an important paper, Furfine (2003) uses exposure data on interbank federal funds to simulate the risk of financial contagion and finds it to be negligible. In contrast, Humphrey (1986) uses data from the Clearing House Interbank Payments System (CHIPS) to simulate the impact of a settlement failure of a major participant in the payment system. He shows that this failure could lead to a significant level of further settlement failures. Upper and Worms (2004) study financial contagion due to interbank exposures in the German interbank market. Through a counterfactual simulation, they find that the failure of a single bank could lead to the breakdown of $15 \%$ of the banking system. Elsinger et al. (2003) use detailed data from the Austrian interbank market and study the possibility of contagious failures due to an idiosyncratic shock. In their simulations, they find the probability to be low. They also find that although the probability of contagious default is low, there are cases in which up to $75 \%$ of the defaults are due to contagion. Although the above papers explore the issue of financial contagion due to interbank exposures, they do not capture the endogenous responses of depositors and creditors during a crisis (Upper 2006). Our paper differs from the papers cited above by using an actual failure in order to test financial contagion in the banking system, in turn allowing us to study the endogenous response of depositors and creditors in the propagation of the crisis. ${ }^{7}$

Another related strand of empirical literature investigates depositor runs on banks during a crisis. This literature explores whether depositors run randomly across banks or run on banks based on fundamentals (i.e., a test between the sunspot-based theory of bank runs by Diamond and Dybvig [1983] versus the fundamental and information-based theory

\footnotetext{
${ }^{6}$ More recently, Gropp et al. (2005) use the tail properties of distance to default to study contagion risk in Europe; they find that contagion risk in Europe is important. Hartmann et al. (2005) study tail risk in major banks in the Euro Area and United States; they find that multivariate tail risks among major banks have recently increased.

${ }^{7}$ Our study is closer to Furfine (2002). He studies the federal funds market during the LTCM and Russian crises and finds that risk premia on overnight lending were largely unaffected and lending volumes increased.
} 
of bank runs by Chari and Jagannathan [1988], Jacklin and Bhattacharya [1988], and Allen and Gale [1998]). ${ }^{8}$ Schumacher (2000) studies depositor behavior in Argentina following the Tequila Shock and finds that depositors concentrate their runs primarily on fundamentally weak banks. Martinez Peria and Schmukler (2001) also find evidence of depositor discipline in Argentina, Mexico, and Chile. Calomiris and Mason (1997) look at the Chicago Banking Panic of 1932 and investigate whether solvent banks failed during the crisis. They find that banks that failed during the panic were ex ante weak banks. ${ }^{9}$ Gorton (1988) studies the banking panics during the U.S. National Banking Era (1865-1914). He finds them not random events but products of revisions in the perceived risk of the banking system based on the arrival of new information. Our paper adds to this literature by including financial linkages of banks with other banks in the bank fundamental characteristic variables and then studying depositor runs.

The rest of this paper is organized as follows. Section 2 describes the institutional details of the Indian banking system. Section 3 provides a description of the event. Section 4 summarizes the data used in the analysis. Section 5 discusses the empirical strategy of the paper along with a discussion of the results. Section 6 provides conclusions and suggests some policy measures.

\section{Institutional details}

Before we proceed to describe the event that we use to study contagion, a brief summary of the institutional setting is helpful to set things in perspective. The Indian banking system primarily consists of three types of banks: public, private, and cooperative banks. There are three different cooperative banks in each state: the state cooperative bank (each state has a cooperative bank), followed by the local district central cooperative bank, and then the urban cooperative banks. The main difference is that the state cooperative bank and the district central cooperative bank are controlled by the local governing body of the state. Note that our sample is limited to urban cooperative banks and does not include state and district co-op banks. Cooperative banks' deposit base is primarily made up of small depositors. One point to take note of is that depositors of cooperative banks are not required to hold an equity claim in the bank. Also, shareholders of cooperative banks have

\footnotetext{
${ }^{8}$ See also Bhattacharya and Gale (1987) and Bhattacharya and Fulghieri (1994).

${ }^{9}$ In the similar spirit Kho et al. (2000) find that the market was able to discern between exposed and nonexposed banks in the emerging market currency crises.
} 
limited liability. Thus, the cooperative structure of the banks does not lead to significant differences in characteristics of depositors as compared with banks that have other ownership structures. With regard to the loan portfolio, it is mandatory for cooperative banks to lend at least $60 \%$ of their loan portfolio to the "priority" sector (see Banerjee and Duflo 2002).

The main regulatory authority of the banking system in India is the Reserve Bank of India (RBI). Cooperative banks, however, come under dual regulation - i.e., they are supervised by the RBI as well as by the local state government. The RBI is responsible for monitoring the banks' portfolios, while the state government is responsible for governance issues. The insurance cover granted under the deposit insurance scheme is Rs. 100,000 (approximately U.S.\$2,000) for each account. The deposit insurance is based on a flat premium. Though deposit insurance is present, there are several delays in processing the claims of depositors, as the central bank first suspends convertibility when a bank approaches failure. After suspension of convertibility, the central bank decides whether to liquidate a bank or arrange a merger with another bank. During this period, depositors are allowed a one-time nominal withdrawal up to a maximum amount that is stipulated by the central bank. In most cases, depositors are allowed a one-time withdrawal of up to Rs. 1,000 (U.S.\$20) per account. The stipulated cash reserve ratio and statutory liquidity ratio to be maintained by the banks are $5.5 \%$ and $25 \%$, respectively. ${ }^{10}$

The interbank market for funds in India is composed of two parts. One is the call money market, which is similar to the federal overnight market for funds. The call money market is mainly dominated by private banks and public sector banks, though some large cooperative banks do have a presence. The other interbank market is the market for direct placement of deposits and borrowings by banks among one another. The cooperative banks are generally very active in this market and use this market to park their surplus funds (mostly with other cooperative banks). The contracts entered in this market take the form of demandable debt, unlike those in the call money market, which are standard debt contracts (contracts in the call money market are entered for a stipulated period of time and cannot be liquidated before maturity). While the funds transacted in the call money market are not

\footnotetext{
${ }^{10}$ Statutory Liquidity Ratio (SLR) is the one which every banking company shall maintain in India in the form of cash, gold, or unencumbered approved securities an amount which shall not, at the close of business on any day, be less than such percentage of the total of its demand and time liabilities in India as on the last Friday of the second preceding fortnight.
} 
insured, the funds placed by banks as deposits in other banks are insured only up to the ordinary deposit insurance levels (Demirguç-Kunt et al. 2005).

\section{Event description}

We now turn to the description of the event that we use to study contagion (see Figure 1 for the event time line). The whole episode started with a fraud in the largest cooperative bank, named Madhavpura Mercantile Co-operative Bank (hereafter referred to as MMCB), in the state of Gujarat. MMCB had granted loans to a stockbroker without appropriate collateral, in contravention of the guidelines prescribed by the central bank. Cooperative banks were not allowed to have direct exposure to stock market or lend to stockbrokers. The amount of loans given to the stockbroker amounted to nearly $80 \%$ of the deposit base (Rs. 10 billion were advanced as industrial loans to stockbrokers without appropriate collateral). On March 8, 2001, some major brokers defaulted on their pay-in obligations to the stock exchange. Rumors were floating around that MMCB had overstretched lending positions to a major stockbroker who had suffered huge losses in his share dealings in a select group of stocks. This led to a run on the bank on March 9 and 12, 2001. Because the bank failed to repay depositors on March 13, 2001, the central bank suspended convertibility and restrained the bank from making payment to depositors beyond Rs. 1,000 per account.

Apart from the fact that MMCB was the biggest cooperative bank in the state, another crucial aspect of the MMCB failure was that it had a significant number of banks connected to it via interbank transactions. Out of the total deposit base of Rs. 12 billion, deposits from other banks constituted about Rs. 6 billion. The primary reason for its large number of connections was that MMCB had the status of a scheduled bank, which allowed it to carry out multi-state operations. ${ }^{11}$ Smaller cooperative banks in the state maintained deposits with MMCB because MMCB provided remittance facilities within and across the state. $^{12}$

Many cooperative banks also used the deposits placed with MMCB to fulfill the statutory liquidity requirements. This setup is similar to the reserve pyramiding that

\footnotetext{
${ }^{11}$ Cooperative banks have branching restrictions similar to those that existed in the United States. A bank is not freely allowed to expand its branch network. It is allowed to open branches in other states/districts only if it obtains permission from the central bank subject to the bank meeting certain criteria in terms of deposit base and capital adequacy.

12 Remittance facility is a mechanism to transfer funds to other areas. For example, a bank that does not have a branch in location $\mathrm{X}$ might use the services of another bank that has a branch at $\mathrm{X}$ to transfer funds to that location. MMCB had provided remittance facility/check collection services free of charge to other banks.
} 
prevailed in the United States prior to the passing of the Federal Reserve Act, which led to the establishment of Federal Reserve Banks (Broaddus 1993). Thus, interbank deposits placed in MMCB were to a large extent exogenous in the sense that these deposits were placed for transactional convenience rather than for direct lending to MMCB. Apart from the linkages that banks had to MMCB due to direct placement of deposits, some banks were also linked to MMCB due to their call money lending and pay orders.

An important point to note is that at the time of failure, the economy of the state was performing well: Gujarat's GDP growth was $9.8 \%$ in 2001 as compared with $0.6 \%$ in 2000 and $-1.6 \%$ in $1999 .^{13}$ The public sector banks witnessed an increase in deposits and also increased the amount of lending in the period after the shock. Furthermore, there were no other frauds in the banking system, and none of the other banks had any lending to the defaulted broker (none of the other banks had any positions to the defaulted brokers that were revealed in the audits ex post by the central bank). Also, ex post in the report released after the investigation of the fraud, it was found that none of the other cooperative banks were involved in the fraud. Thus, the shock was idiosyncratic as it affected only the failed bank. $^{14}$

After the collapse of MMCB, there was a huge debate about whether MMCB should be bailed out. A committee was convened to study the possibility of its revival. The fundamental aspect of the revival plan addressed by the committee was to choose one of the three following options: closure, merger or takeover, or comprehensive financial and operational restructuring. Based on the recommendations of the committee, it was finally decided in August 2001 that MMCB would be revived. The revival scheme was organized in terms of a privately arranged bailout. The revival package required the participation of all the cooperative banks in the state, contributing $4 \%$ of their deposit base to the revival fund. This money was to be insured by a guarantee provided by the government. The revival package, however, did not insure the deposits that banks already held with MMCB. The deposits and call money exposures that banks had with MMCB prior to its failure were to be retained and converted into term deposits for a period of four years at $7.5 \%$ per annum.

\footnotetext{
${ }^{13}$ Bank failures depend on the general economic conditions. For example, the stance of monetary policy affects loan defaults and, hence, the probability of bank failures (Rajan 2006, Jimenez et al. 2008, Ioannidou et al. 2008, and Maddaloni and Peydró 2009). Therefore, the changes in general economic conditions by affecting the likelihood of bank failures make it difficult to disentangle the channels of contagion.

${ }^{14}$ Iyer and Puri (2007) exploit the same shock to study the characteristics of depositors that run in one of the banks in our sample and find that the runs started only after the failure of MMCB.
} 
Although there was a guarantee provided by the government, the revival scheme never took off. Most of the cooperative banks in the state were reluctant to contribute funds. The committee in charge of implementing the revival scheme also noted that the recovery of the amount lent to the stock brokers was very unlikely.

After the failure of MMCB, the immediate concern of the central bank was to limit the contagion. The central bank was mainly concerned with the propagation of the crisis due to interbank connections. This fact was highlighted in the statement made by the governor of the central bank in his monetary policy address for 2001-2002. He stated, "Recent experience has shown that irresponsible and unethical behavior on the part of even a few cooperative banks in the country can have some contagion effect beyond the particular area or the state concerned.” The immediate policy response by the central bank was to limit the amount of exposure banks could have in the call money market. As on April 2001, cooperative banks were not allowed to borrow more than $2 \%$ of their deposit base as of the end of March in the previous year. There was, however, no restriction on lending in the call money market, and the central bank was ready to provide liquidity to banks against appropriate collateral if the need arose. The central bank also noted that parking of funds by cooperative banks with other cooperative banks posed a systemic risk. In response, it issued a directive in May 2001 asking all the cooperative banks not to renew or place fresh deposits with other cooperative banks. It was, however, left to the discretion of the banks to decide if they wanted to unwind their deposits prematurely, although it was stipulated that by the end of June 2002, they should unwind their deposits with other cooperative banks. Another regulatory response of the central bank, immediately after the failure, on March 16, 2001, was to issue a public statement that all banks had adhered to the prescribed norms related to stock market lending.

\section{Data}

Because there is no single source that has all the balance sheet information (either in paper or in electronic format), we had to hand collect annual reports of banks. Given the difficulty of the task, we streamlined the data collection. We first limit our analysis to cooperative banks located in the state of Gujarat as there were only very few banks outside 
the state of Gujarat that had connections to the failed bank. ${ }^{15}$ We further limit our sample to banks that have a deposit base of more than Rs. 250 million (5 million dollars) as of March 31, 2001. Note that this understates the effect of runs, as some banks that faced withdrawals between the failure of MMCB and March 31, 2001, whose deposit base fell below Rs. 250 million are not included in the sample. We find that using this cutoff led to a total of 142 banks, constituting $87 \%$ of the total deposit base of the cooperative banks in Gujarat and $13 \%$ of the total banking system in the state. Moreover, these banks cover a major portion of the linkages with the failed bank. ${ }^{16}$ For the 142 banks in the sample, we obtain data on their deposit figures as on March 31, 2000; December 31, 2000; March 31, 2001; and December 31, 2001, along with the relevant balance sheet variables as on March 31, 2000, and March 31, 2001. Note that the deposit data as of December 31, 2000, and of December 31, 2001, is obtained from the central bank because cooperative banks publicly report their deposit data only as of March 31 of every year.

We also have data on the outstanding credit and debit position each bank has with MMCB as on March 13, 2001 (date of failure). In addition, we have data on the aggregate outstanding level of claims that each bank has with and from other banks in the interbank market as of March 31, 2001. All these data are obtained from the central bank. Thus, for each ongoing bank, we know: (i) its exposure to the failed bank (MMCB); (ii) the amount of credit outstanding it has with other ongoing banks in the system; (iii) the amount of funds it has from other ongoing banks in the system. An important point to note is that all these interbank claims are unsecured. We also compile deposit rates offered by banks from the annual reports (i.e., on March 31, 2001, and on March 31, 2002), if they were available. Finally, we collected information on media articles about bank runs that were published during the crisis. We first collected information on the articles that appeared in the national newspapers and then looked for additional information in the regional newspapers. In addition, we also looked in the annual reports of banks to check for voluntary release of information pertaining to the credit and debit outstanding with the failed bank (MMCB).

\footnotetext{
15 Banks headquartered in the region of Kutch were also excluded from the analysis, as there was an earthquake that severely affected this region on January 26, 2001 (prior to the MMCB failure). The central bank and the state government provided several concessions to banks located in this region to facilitate economic growth. Also, there was a huge increase in deposits in banks in this region as aid agencies opened accounts to help facilitate the rehabilitation process.

${ }^{16}$ The placement of deposits and dealings between cooperatives and private and public banks is limited. There were no private or public banks that had deposits placed with MMCB.
} 


\section{Empirical results}

We now return to the central question of whether there is financial contagion due to interbank linkages. To study financial contagion due to interbank linkages with the failed bank, we first construct a variable called exposure that represents the credit outstanding of a bank with the failed bank (MMCB) as fraction of its total assets. One point to take note of is that the failed bank (MMCB) did not lend to any bank in our sample. Notice also that the variable exposure is measured on March 13, 2001 (as on the date of the failure). We then construct a variable called deposit growth that for each bank captures the change in the level of deposits between March 31, 2001, and December 31, 2001. ${ }^{17}$ We also define a dummy variable that reflects large deposit withdrawals (tail risk). Since we only have 142 observations in our sample, we select the tail risk as the $20 \%$ of the observations in our sample with the highest deposit withdrawals. This corresponds to a cutoff of deposit withdrawals greater than $12.75 \%$ (i.e., deposit growth lower than $-12.75 \%$ ). Thus, large deposit withdrawals is a dummy variable that takes the value of 1 if deposit growth is lower than or equal to $-12.75 \%$, and 0 otherwise. Note that even if we use other thresholds like $15 \%$ we do not find any change in the results of the paper.

To control for other factors that could influence deposit withdrawals, we construct several measures using March 31, 2001, balance sheet information. We measure bank profitability by return on assets ratio (see the Appendix for exact definitions of all the variables). We also use the capital-to-asset ratio as measure of financial health of the bank. We also control for the size of banks. The measures that we use to proxy for riskiness of banks, or susceptibility to a crisis, are: the ratings by the regulator (which classifies banks as weak or not) and credit-to-deposit ratio. Ideally, we would like to use the level of nonperforming assets as a measure of riskiness, but cooperative banks are not required to disclose the details of non-performing assets. The ratings by the regulator provide a substitute for the level of non-performing assets. ${ }^{18}$ The credit-to-deposit ratio captures the

\footnotetext{
${ }^{17}$ We use change in the aggregate level of deposits to construct the measure because data on uninsured versus insured level of deposits is not available. Although insured depositors should not have an incentive to run, the delays in payment due to partial suspension of convertibility reduces the effectiveness of the deposit insurance scheme. Martinez Peria, and Schmukler (2001) find that insured depositors disciplined banks in Argentina, Mexico and Chile. They attribute this behavior to problems in the implementation of the deposit insurance scheme.

${ }^{18}$ Banks whose owned funds have been eroded to the extent of $25 \%$ or more by un-provided for bad and doubtful debts are classified as weak. Banks that have overdues exceeding $50 \%$ of loans outstanding, or banks not complying with minimum share capital requirements or viability norms prescribed by the central bank, are also classified as weak. Banks that are classified as weak have restrictions placed on them in terms of dividend payouts and disposal of assets.
} 
illiquidity risk of a bank. We also define a dummy variable called media release that takes a value of 1 for a bank if a report appeared in the newspapers about runs in the bank, and zero otherwise. Note that most of the media articles just stated a bank was facing a huge depositor withdrawal. Also, all the articles except one appeared immediately after the failure-i.e., between March 13, 2001, and March 31, 2001. In addition, to control for local macroeconomic factors that could affect deposits, we use dummies for districts where banks are headquartered as the bulk of a cooperative bank's business and deposit base is in the district where it is headquartered (Mian 2006).

Table 1 provides summary statistics of the data. We find that on average, banks experience a negative deposit growth (4.96\% loss in deposits) in the period between March 31, 2001, and December 31, 2001. We also see that there is wide degree of variation in the deposit growth across banks (the standard deviation is 13.3\%), with some banks experiencing a 50\% loss in deposits, while other banks experience a positive deposit inflow to the tune of $50 \%$. The average deposit growth in the period between March 31, 2000, and March 31, 2001, is $14.1 \%$. The average exposure that banks have to the failed bank is $3.27 \%$ of their total assets. The average of other interbank lending (lending in the interbank market apart from the exposure to the failed bank) is $2.9 \%$. The average capital-to-asset and return-on-assets ratios are $11 \%$ and $1 \%$, respectively. The average credit-to-deposit ratio is $64 \%$ (refer to Table 1 for summary statistics of the remaining variables).

A detailed look at the exposure levels of banks shows that out of a total sample of 142 banks, 121 banks are connected to the failed bank, with the highest exposure level being $23 \%$ of total assets. The average exposure that banks have to the failed bank is $3.27 \%$ of their total assets, while the median is $0.5 \%$. Out of the total of 121 banks that are connected to the failed bank, 20 banks have more than 9.21\% (average plus one standard deviation of banks with positive exposure) of their assets invested in the failed bank. We define these banks as having high exposure. Twenty-one banks have exposure levels between 3.83\% (average of banks with positive exposure) and 9.21\%. We define these banks as having medium exposure. Finally, 80 banks have positive exposure levels but lower than $3.83 \%$. We define these banks as having low exposure.

Decomposing the deposit growth and the probability of large deposit withdrawals for different categories of exposure, we can see that the deposit growth that banks experience is decreasing in the exposure levels to the failed bank (figure 2a). We also see that the probability of large deposit withdrawals is increasing in the exposure levels. For 
instance, banks that are in the high-exposure region face a 35\% probability of facing large deposit withdrawals, while the corresponding probability is only $4.76 \%$ for banks in the zero-exposure region. Figure $2 \mathrm{~b}$ presents the relationship between exposure and deposit growth for the period before the failure of the large bank. The results are in sharp contrast to those reported in Figure 2a. In the period before the failure of the large bank, we see that there is no relation between exposure levels and deposit flow (the probability of large deposit withdrawals is also zero for all levels of exposure). Moreover, we find that banks with a high level of exposure to the failed bank do not differ in ex ante characteristics as compared with banks with low levels of exposure. As the results in Table 2 show, there are no significant differences in terms of profit, risk (proxied by deposit rate), and size across these two categories of banks (not reported; even if we compare ex ante characteristics of banks as on March 31, 2000, we find similar results).

\subsection{The effect of exposure on deposit withdrawals}

From Figures 2a and 2b, there appears to be a correlation between exposure and deposit withdrawals only after the failure of the large bank. To further examine whether the level of exposure to the failed bank has an effect on deposit withdrawals, we first examine the effect of exposure on deposit growth using a cross-sectional regression approach. In Table 3, column 1, controlling for other fundamental characteristics of banks and local macroeconomic conditions, we see that exposure to the failed bank is a significant predictor (at 1\%) of deposit growth. We find that banks with higher levels of exposure to the failed bank experience lower growth in deposits. We also find that banks with higher returns on assets have significantly higher deposit growth. Banks that are classified as weak by the regulator experience lower deposit growth. Furthermore, banks with higher fraction of illiquid assets -- proxied by credit-to-deposit ratio -- have a lower deposit growth. We also find that the media release dummy is highly significant in explaining deposit growthi.e., banks that have a media report about them have lower growth in deposits after the media release.

As it is possible that exposure could just be proxying for other characteristics of banks, like distance from the failed bank or a correspondent banking relationship with the failed bank, in column 2 we introduce controls both for correspondent banking relationship with the failed bank and for distance from the failed bank. In column 2, we also control for deposit growth in the previous year (between March 31, 2000, and March 31, 2001) to capture past performance of banks. As the results in column 2 show, we find that lagged 
deposit growth has a positive and significant effect on current deposit growth. We do not, however, find any significant effect of correspondent banking relationship or distance from the failed bank on deposit growth. More important, we find that despite these controls, exposure to the failed bank continues to have a significant negative effect on deposit growth. In column 3, we look at the effect of deposits held in other banks (apart from the failed bank) on deposit growth. Interestingly, we find that only the level of exposure to the failed bank has a significant negative effect on deposit growth. There is no significant effect of higher lending to other banks on deposit growth.

In column 4, we introduce a dummy variable that takes the value of 1 for banks with no exposure to the failed bank, and zero otherwise. The dummy variable is statistically and economically significant: banks with positive exposure to the failed bank on average experience a negative deposit growth of $6.2 \%$, as compared with banks with no exposure. We also find that banks with high levels of exposure to the failed bank experience, on average, an additional lower deposit growth of $8.6 \%$, as compared with banks with low exposure (column 5). The preliminary results in Table 5 suggest that depositor withdrawals are based both on the exposure to the failed bank and on bank fundamentals.

Although in Table 3 we find that higher level of exposure to the failed bank has a negative effect on deposit growth, theoretical models of interbank contagion (Allen and Gale 2000, Dasgupta 2004, Brusco and Castiglionesi 2005) predict that higher exposure to the failed bank leads to a higher probability of large deposit withdrawals. Hence, to check whether exposure to the failed bank affects the probability of large deposit withdrawals, we run probits where the dependent variable is a dummy variable that takes the value of 1 if deposit growth is lower than or equal to $-12.75 \%$ (large deposit withdrawals). With this cutoff, 20\% of the banks in our sample suffer large deposit withdrawals (none of the results of the paper are altered if we use other cutoffs, like -15\%).

As we can see in Table 4, column 1 to column 3, higher exposure to the failed bank increases the probability of facing large deposit withdrawals. The variable exposure is statistically significant at $1 \%$. In columns 4 and 5, we find that the dummy for banks with high exposure is statistically significant at $1 \%$. Moreover, if we derive the marginal effects for the probit in column 5, we find that (at the average level) a bank with a high level of exposure (vis-à-vis a bank with a low level of exposure) experiences an increase in outcome probability of large deposit withdrawals of 0.34 . Hence, not only is exposure statistically significant, but it is also economically significant. Notice that in column 1 , 
when we put district controls, we lose many observations because many district controls perfectly predict the outcome (we have 16 district controls and only 142 banks). Nevertheless, exposure is still significant at $1 \%$. Also notice that most of the bank fundamental variables have similar effects (in terms of signs) as those reported in Table 3. All in all, the results in Tables 3 and 4 suggest that exposure impacts deposit withdrawals.

\subsubsection{The nonlinear effect of exposure}

Apart from exposure to the failed bank leading to large deposit withdrawals, theoretical literature (Allen and Gale 2000, Dasgupta 2004, Brusco and Castiglionesi 2005) also points toward nonlinearities in the effect of exposure on large deposit withdrawals and, possibly, on deposit growth. To investigate this hypothesis, we run a piecewise linear regression (see Morck et al. 1988). As we can see from Table 5, column 1, we cannot reject that the coefficient for banks in the low exposure region is different from zero. In addition, in column 2, the dummy for banks with zero exposure has a positive and significant coefficient, in turn implying that banks with zero exposure have higher deposit growth. More important, we reject the hypothesis that the coefficient of the high-exposure region is equal to the coefficient of the low-exposure region, thus suggesting that the effect of exposure on deposit growth is nonlinear.

In columns 3 and 4, we investigate nonlinear effects of exposure on the probability of large deposit withdrawals. As the results show, we find only that banks in the highexposure region face a higher probability of large deposit withdrawals. In addition, we reject that the coefficients are equal. Interestingly, we find that banks with zero exposure experience lower probability of large deposit withdrawals. All in all, these results suggest that there is a nonlinear effect of exposure on deposit withdrawals. In particular, the sensitivity of exposure on deposit withdrawals is greater for banks with high levels of exposure.

\subsubsection{The immediate effect of exposure on deposit withdrawals}

To analyze the immediate impact of exposure on deposit growth (between March 13 and 31, 2001), we use data on deposit growth for the period between December 31, 2000, and March 31, 2001. In addition, we also use balance sheet data as on March 31, 2000. In Table 6, column 1, we find that exposure has a significant negative effect on deposit growth. In column 2, we also find that the dummy for banks with high levels of exposure is significant and has a negative effect on deposit growth. When we run the piece-wise linear regression, 
we again find a nonlinear effect: only banks with high levels of exposure experience lower deposit growth (column 3). The results in Table 6 suggest a negative correlation between exposure to the failed bank and deposit growth even in the period immediately after the failure. To make sure that the correlation between exposure to the failed bank and deposit growth is a result of the failure and not driven by omitted characteristics, we look at the effect of exposure to the failed bank on deposit growth in the period between December 31, 2000, and March 31, 2000-i.e., the period before the crisis. As the results in column 4 show, we find that there is no effect of exposure to the failed bank on deposit growth in the period before the failure. This suggests that the effect of exposure on deposit growth is primarily due to the failure of the large bank.

\subsubsection{The effect of exposure on deposit rate change}

While the results so far suggest that exposure to the failed bank has a significant effect on deposit withdrawals, it could be possible that banks with higher exposure reduced their rate offered on deposits (due to regulatory pressure), thereby facing higher deposit withdrawals. In order to investigate this possibility, we analyze whether changes in the deposit rate paid by banks are related to the level of exposure. As the results in Table 7, column 1, show, we do not find any significant relationship between change in the deposit rate and exposure levels. Moreover, the correlation coefficient between the high-exposure dummy and the deposit rate change is -0.03 . These results suggest that the effect of exposure on deposit withdrawals is not due to change in deposit rates.

\subsubsection{Communication of exposure in the banks' annual reports}

The finding that banks with higher levels of exposure to the failed bank experience higher deposit withdrawals raises the question of whether depositors have access to the information on the outstanding credit position of banks with the failed bank. One possible way depositors might get this information is through voluntary disclosure by banks of their interbank positions in their annual reports. To investigate the possibility of banks voluntarily releasing information in the period in which we measure deposit withdrawals, we check whether information on exposure is provided by banks in their 2001 annual report -- released between July and December 2001. We find that some banks voluntarily release information.

In order to further investigate the characteristics of banks that release information on exposures to the failed bank, we run a probit, the results of which are reported in Table 
7, column 2. We find that banks with lower levels of exposure to the failed bank are more likely to release information. ${ }^{19}$ We also find that banks that have a media release are less likely to release information. Interestingly, we find that banks that have a correspondent banking relationship with the failed bank are more likely to release information. These results are partially consistent with the predictions of games of voluntary disclosure with verifiable information, where good types have an incentive to disclose their type (OkunoFujiwara et al. 1990, Vives 2004). However, we do not find complete unraveling of information.

When we reestimate the deposit growth regression (not reported) and the probability of large deposit withdrawals excluding the banks that released information, we find that exposure to the failed bank is still a highly significant predictor of withdrawals in this subsample (column 3). In other words, even for banks that reported no information on exposure to the failed bank, the exposure level is a significant predictor of deposit withdrawals. This, coupled with the findings in Table 6 that banks with high level of exposure experience lower deposit growth immediately after the failure, suggests that depositors might be acting on private information obtained through monitoring (Calomiris and Kahn 1991) and/or on alternative channels like rumors or word of mouth communication (Kelly and O’Grada 2000, Iyer and Puri 2007).

\subsubsection{Instrumental variable regressions}

One of the problems of the regressions reported in Table 3 is that banks that are badly performing (experiencing a lower deposit growth) may choose higher levels of exposure. Therefore, to address this self-selection problem and get a better understanding of the causal link between exposure and deposit growth, we use the instrumental variable approach. For identification, a natural candidate to instrument for exposure is a variable that proxies whether banks lend in the interbank market (excluding lending to the failed bank): banks that lend in the interbank market are also likely to lend to the failed bank and vice versa. We, therefore, create a dummy variable that takes the value of 1 for banks that have deposits outstanding (lend) in the interbank market (excluding exposure to the failed bank), zero otherwise. In particular, the dummy for banks that lend in the interbank market does not have any direct effect on deposit withdrawals.

\footnotetext{
${ }^{19}$ While interpreting the results from the probit, one should keep in mind that we do not have deposit changes before the information release by banks, which could have influenced the decision to release information.
} 
In Table 7, columns 4 and 5, we run an instrumental variable probit for the effect of exposure on large deposit withdrawals (for the period between March 31, 2001, and December 31, 2001). To instrument for exposure, we use the dummy that takes a value of 1 for banks that also lend to the other banks in the interbank market (excluding the lending to the failed bank). As we can see in the first stage regression (column 4), the dummy for banks that have an overall lending presence in the interbank market is a highly significant determinant of exposure. In particular, the $t$-statistic of the hypothesis that the overall lending presence-based instrument can be excluded from the regression--i.e. that the coefficient on it is 0 , equaling 3.46. Hence, the F-statistic of the exclusion hypothesis ( $F=11.97)$ exceeds the rule-of-thumb threshold of 10 recommended by Staiger and Stock (1997) to avoid weak instrument concerns. More important, the second stage regression estimates (column 5) suggest that the component of exposure to the failed bank predicted by the overall lending presence in the interbank market has a highly significant effect on the probability of facing large deposit withdrawals. ${ }^{20}$

\subsection{Implications of interbank contagion}

The results so far show that exposure to the failed bank has a significant effect on deposit withdrawals. Now we study the further implications of interbank contagion.

\subsubsection{Interbank linkages among ongoing banks}

We proceed to investigate whether banks with a higher fraction of their deposits held by other banks (i.e., banks with higher borrowing from the interbank market) face higher deposit withdrawals. ${ }^{21}$ There are several possible reasons why banks with higher fractions of deposits/borrowings from other banks may face higher deposit withdrawals: (i) banks may liquidate their interbank deposits in order to obtain liquidity in a crisis time; (ii) banks with higher interbank lending may fear contagion due to interbank linkages, thus liquidating their deposits in other banks -- especially in banks with higher levels of exposure to the failed bank; (iii) banks might unwind their deposits in other banks due to the mandate of the central bank to not renew deposits in other banks.

In Table 8, column 1, we do not find that banks with a higher fraction of their deposits held by other banks experience lower deposit growth. The finding that the fraction

\footnotetext{
${ }^{20}$ We also examined the effect of predicted exposure on deposit growth and found similar results (not reported).

${ }^{21}$ From Table 3 and 4, column 3, we find that lending in the interbank market (excluding the lending to the failed bank) does not affect deposit withdrawals.
} 
of borrowings from other banks does not directly affect deposit growth suggests that the mandate of the central bank was not binding. It also suggests that banks did not randomly liquidate their deposits in the interbank market. However, interestingly, we find in columns 2 and 3 that the interaction of exposure and fraction of borrowings from other banks is both economically and statistically significant. This implies that the effect of exposure to the failed bank on deposit withdrawals is higher for banks that borrow more from the interbank market.

It could be possible that banks with higher exposure to the failed bank borrow more from the interbank market in order to obtain liquidity. If this were true, the interaction of exposure and fraction of deposits from other banks should be significant but not because of fear of banking contagion. To address this concern, we regress fraction of deposits from other banks on bank fundamentals -- including exposure. From the results in column 4, we do not find any significant relationship between bank fundamentals and the fraction of deposits from other banks. More important, we do not find any relationship between exposure levels to the failed bank and the fraction of deposits from other banks. In sum, the finding that the interaction variable between exposure and interbank borrowings affects deposit withdrawals suggests that banks might liquidate their deposits in other banks with high levels of exposure to the failed bank due to the fear of further contagion. Also, the results from Table 8 show that for banks with lower exposure to the failed bank, the fraction of deposits from other banks do not affect deposit withdrawals, thus suggesting that there is no random panic in the interbank market.

Given the findings in Table 8, columns 1 through 4, a natural question that arises is whether the effect of exposure on deposit withdrawals that we find in Table 3 and 4 is primarily driven by the liquidation of deposits by banks. To address this concern, we run the regressions for banks that do not have deposits from other banks. We find that even for banks that have no deposits from other banks, exposure has a significant effect on deposit withdrawals (column 5 and 6), suggesting that retail depositors also withdrew during the crisis.

\subsubsection{The effect of exposure when bank fundamentals are stronger}

The results so far suggest that higher exposure to the failed bank significantly increases deposit withdrawals (i.e., contagion due to interbank linkages). In addition, the results also suggest that depositor withdrawals are higher in banks with lower fundamentals. However, 
from a policy point of view, it is important to understand how the magnitude of contagion experienced is related to fundamentals--i.e., which factors help mitigate the extent of contagion. Theory (Allen and Gale 2000, Dasgupta 2004 Brusco and Castiglionesi 2005) also suggests that contagion due to interbank linkages should be higher when bank fundamentals are weaker -- i.e., the effect of higher exposure on deposit withdrawals should be lower for banks with stronger fundamentals since they can better withstand the crisis. To investigate this hypothesis, we interact exposure with variables that proxy for bank fundamentals. ${ }^{22}$ Table 9 presents the results.

From column 1 and 5, we find that the effect of exposure on large deposit withdrawals is lower for banks with higher capital-to-asset ratios. ${ }^{23}$ From column 2 and 5, we find that the effect of exposure on large deposit withdrawals is increasing in the number of depositors in the bank. We also find that the impact of exposure on deposit growth is stronger for banks with higher numbers of depositors (column 6). ${ }^{24}$ This result suggests that contagion is higher when there is higher likelihood of coordination problems among depositors (proxied by the number of depositors). This finding is consistent with the theories of bank runs using global games where coordination problems that end up in bank runs are a consequence of weak bank fundamentals (Rochet and Vives 2004, Goldstein and Pauzner 2005). From columns 3 and 6, we also find that the impact of exposure on deposit growth is stronger for banks classified as weak ex ante by the regulator. Also, we find that the effect of exposure on large deposit withdrawals is higher for banks classified as weak. From column 6, we find that the impact of exposure on deposit growth is stronger for smaller banks. ${ }^{25}$ Finally, in columns 5 and 6 we present the results of all the interactions, including the interaction of exposure and interbank borrowings.

The finding that the impact of exposure on contagion depends on bank fundamentals could be due to the important role other banks play as depositors. Hence, to

\footnotetext{
${ }^{22}$ Notice that we normalize the interaction variables of exposure with bank fundamentals. We do this both to gain in efficiency and also to reduce the correlations among the regressors: e.g., the variable weak has two values ( 0 and 1$)$; hence, if we would not normalize the interaction variables, then, when weak is equal to 0 , the interaction term of exposure and weak would equal zero independently of whether exposure is high or low. Therefore, without normalizing, then (i) the correlation between weak and exposure $\times$ weak would be higher and (ii) we would not differentiate between weak banks with higher vs. weak banks with lower exposure.

${ }^{23}$ From column 6, we find that (at 11\%) the effect of exposure on deposit growth is higher for banks with lower capital-to-asset ratio.

${ }^{24}$ Notice that we use the number of depositors as on March 31, 2000, because the number of depositors as on March 31, 2001, is partially determined by the levels of exposure to the failed bank.

${ }^{25}$ From column 5, we find (at 14\%) that the effect of exposure on large deposit withdrawals is higher for smaller banks.
} 
analyze the role of retail depositors, in column 7 we analyze the same regression as in column 6, restricting the sample to banks that do not have other banks as depositors. The results in column 7 suggest that (retail) depositors also run more on banks that have higher exposure and weaker fundamentals. ${ }^{26}$

All in all, these results suggest that contagion due to interbank linkages is stronger when bank fundamentals are weaker. These results are consistent with theories of bank runs based on fundamentals (Chari and Jagannathan 1988, Gorton 1988, Jacklin and Bhattacharya 1988, Calomiris and Gorton 1991, Calomiris and Kahn 1991, Allen and Gale 1998). In addition, these results suggest that the effect of an idiosyncratic shock on the rest of the banking system is higher when both exposure of the banking system to the failed bank is higher and fundamentals of the banking system are weaker. As discussed later, this has important policy implications.

\subsection{Real consequences of financial contagion}

While interbank exposures act as a channel of financial contagion, it is important to understand if there are real economic effects. We find that higher bank exposure to the failed bank implies more liquidity problems, both stemming from retail depositors and from bank depositors. These problems could have a direct negative impact on bank profits. In addition, banks can react to the funding problems either by decreasing liquid assets and/or by decreasing loans that can further reduce bank profits. We, therefore, examine whether banks with higher exposure experience a reduction in loan, credit-to-deposit ratio, and profitability.

From Table 10, columns 1 and 2, we find that banks with higher exposure experience lower loan growth (negative loan growth). ${ }^{27}$ In addition, we do not find any significant change in the credit-to-deposit ratio for banks with higher level of exposure (column 3), thus suggesting that banks offset reduction in deposits with a correspondingly similar reduction in loans rather than a reduction in liquid assets. Interestingly, we find that banks that are more profitable reduce their credit-to-deposit ratio. There are two possible reasons. One possibility is that banks rebalance their portfolios toward more liquid assets in light of the crisis. Alternatively, it is also possible that more profitable banks gain deposits

\footnotetext{
${ }^{26}$ We also find similar results if we analyze large deposit withdrawals.

${ }^{27}$ Notice that we do not include weak banks in the loan growth regressions, because these banks have regulatory restrictions that prevent them from freely adjusting their loan portfolio (our results are robust, even if we run the estimations including weak banks).
} 
in the crisis and then hoard on this liquidity rather than increasing their lending. Finally, not surprisingly given the previous results, we also find that banks with higher exposure have a lower growth in profitability (see columns 4 and 5).

Although the results above suggest that banks with higher level of exposure cut back on loans and also experience a decline in profits, to analyze the real economic effects in the aggregate, one needs to examine whether other banks increase their loans to bridge the deficit. Thus, to further investigate the real economic effects of the financial contagion, we first examine whether some banks gain competitively from the failure of others. We examine whether banks with low exposure to the failed bank gain more deposits and, especially, in areas where the average level of exposure of other banks is high (these are the areas that are likely to face higher deposit withdrawals and thus there is maximum opportunity to gain deposits competitively). In Table 11, column 1, we first report that banks with lower exposure gain deposits. Moreover, in column 2 we interact the average exposure of other banks in the same district with a low-exposure dummy. Interestingly, we find that banks with lower exposure gain more deposits when the average exposure level of other banks in the district is high. This suggests that banks with lower exposure competitively gain deposits in districts in which the exposure, and hence the deposit loss, of other banks is high. In addition to banks competitively gaining deposits, we also find that banks suffer higher deposit withdrawals in areas where the average level of exposure of other banks is high, thus suggesting that there is some spillover of pure contagion. In column 3, we control for the number of other banks in the same district and find similar results.

Although banks with low exposure competitively gain deposits, in column 4 we investigate whether they also increase their lending. We do not find any significant increase in lending immediately. To further investigate whether lending increased in the medium term in column 5, we examine the loan growth for period between December 2001 and March 2002. We again do not find any significant increase in loans. These results suggest that there are lasting real effects stemming from financial contagion due to interbank linkages. One possible reason for the previous findings is that banks might hoard excess liquidity during a crisis, especially when the increase in deposits comes as a result of withdrawals from other banks in the neighborhood with high exposure. Finally, in column 6, we do not find any significant increase in profitability for banks that gain deposits competitively. 
In sum, given that bulk of the borrowers of these banks are of small size and might find it difficult to obtain credit from other sources (Khwaja and Mian 2007, Jiménez et al. 2009), the results taken together suggest that there are real economic effects associated with interbank contagion.

\section{Conclusions and Policy Implications}

This paper exploits an idiosyncratic and sudden shock caused by a large-bank failure, in conjunction with precise data on interbank exposures, to test for financial contagion due to interbank linkages. First, we find robust evidence that banks with higher interbank exposure to the failed bank experience higher deposit withdrawals. To further push on causality, we instrument for exposure to the failed bank using the overall lending presence in the interbank market (excluding lending to the failed bank) and find similar results. We also find that the effect of exposure on deposit withdrawals is nonlinear. Second, we find the following two main implications of contagion: the magnitude of interbank contagion is higher for banks with weaker fundamentals, and interbank linkages among surviving banks (apart from linkages to the failed bank) further propagate the shock. These results lend support to the theories of financial contagion due to interbank markets (Allen and Gale 2000, Dasgupta 2004, Brusco and Castiglionesi 2005). Finally, our results suggest that there are real economic effects associated with interbank contagion in terms of net bank loan supply reduction and lower profits.

Our results have important policy implications, both for prudential regulation and for crisis management. Since we find that interbank linkages transmit shocks, regulators and banks can devise ex ante risk management systems to curtail excessive exposure to single institutions in order to limit the destabilizing effects that could arise from idiosyncratic shocks. Another potential solution could be that bank capital requirements take into account the concentration risk of large single exposures while taking into consideration the costs of limited liquidity provision. Alternatively, there could be limits imposed on the extent to which banks could rely on interbank market funding to meet their liquidity needs, especially if these are large banks.

The other interesting policy implication stemming from our results is that systemic risk implications of a failure of a large financial institution are very important, especially when both the rest of the financial system has (i) a high interbank exposure to the failed 
institution, and (ii) weak fundamentals. Therefore, our paper helps in better clarifying the circumstances in which bailouts and/or lender of last resort (LoLR) policies are desirable: e.g., if the fundamentals of the banking system are strong, bailout may not be necessary since the costs associated with contagion may be lower than the costs associated with bailouts (moral hazard and fiscal costs). ${ }^{28}$ In contrast, if a highly connected bank fails at a time when the banking system fundamentals are weak, a bailout may be necessary to

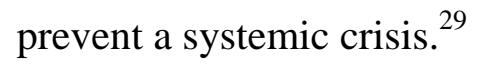

How far can one generalize these conclusions? Given that the analysis is carried out in the context of the Indian banking system (primarily cooperative banks), where the magnitude of interbank operations is still limited, one could expect that the risk of interbank contagion would be higher in banking systems where banks rely heavily on interbank operations (more generally in systems in which counterparty default risk is important). In addition, one could also expect that in banking systems with higher levels of transparency, the role played by bank fundamentals in affecting the magnitude of contagion could be even stronger. Finally, the current crisis has dramatically shown the fragility of interbank markets. One key area for future research would be to understand the reasons of liquidity dry-ups in the interbank markets during the crisis: is it counterparty risk or hoarding of liquidity due to future liquidity needs? We believe that answering these questions is an important area for future research.

\footnotetext{
${ }^{28}$ See also Goodfriend and King (1988), Rochet and Tirole (1996), Holmström and Tirole (1998), Acharya and Yorulmazer (2007a,b).

${ }^{29}$ The following statement made by Ben Bernanke, Chairman of the Federal Reserve in October 2008, after Lehman Brothers' failure when the U.S economy was in a downturn highlights that bailouts may be necessary to prevent a systemic crisis especially when the banking system fundamentals are weak. He said, "In the future, the Treasury will have greater resources available to prevent the failure of a financial institution when such a failure would pose unacceptable risks to the financial system as a whole."
} 


\section{Appendix}

\section{Definition of the variables}

- Deposit growth is $\log \left(\mathrm{D}_{\mathrm{t}} / \mathrm{D}_{\mathrm{t}-1}\right)$ where $\mathrm{D}_{\mathrm{t}}$ is the level of deposits as on December 31,2001 , and $\mathrm{D}_{\mathrm{t}-1}$ is the level of deposits as on March 31, 2001.

- Large deposit withdrawals is a dummy variable that takes the value of 1 if deposit growth is lower than or equal to $-12.75 \%$ (in effect, $20 \%$ of the banks in our sample exhibit large deposit withdrawals).

- Exposure is the credit outstanding of a bank with the failed bank divided by its total assets as on March 13, 2001.

- Dummy high exposure is a dummy variable that takes the value of 1 if exposure is higher than or equal to 9.21\% (average plus one standard deviation of exposure if exposure is greater than zero).

- Dummy medium exposure is a dummy variable that takes the value of 1 if exposure is higher than or equal to $3.83 \%$ (average of exposure if exposure is greater than zero) and lower than $9.21 \%$.

- Dummy low exposure is a dummy variable that takes the value of 1 if exposure is lower than $3.83 \%$ and higher than $0 \%$.

- Dummy zero exposure is a dummy variable that takes the value of 1 if exposure is equal to $0 \%$. All the dummy variables take the value of zero otherwise.

- High exposure is equal to exposure minus 0.0921 if exposure is greater than or equal to $9.21 \%$ and is equal to zero if exposure is lower than 9.21\% (average plus one standard deviation of exposure if exposure is greater than zero).

- Medium exposure is equal to exposure minus 0.0383 if exposure is greater than or equal to $3.83 \%$ and lower than $9.21 \%$; is equal to zero if exposure is lower than $3.83 \%$ (average of exposure if exposure is greater than zero); and is equal to 0.0921 if exposure is greater or equal to $9.21 \%$.

- Low exposure is equal to exposure if exposure is lower than $3.83 \%$; is equal to zero if exposure is 0 ; and, is equal to 0.0383 if exposure is greater than or equal to $3.83 \%$.

- $\quad$ Return on assets is the profits of the bank divided by its total assets as on March 31, 2001.

- $\quad$ Size is the log of total assets of the bank as on March 31, 2001.

- Media is a dummy variable that takes the value of 1 if a report about the bank appeared in newspapers in the period between March 13 and 31, 2001, except for one bank.

- Weak is a dummy variable that takes the value 1 when a bank is classified as weak by the central bank as on March 31, 2001.

- $\quad$ Credit-to-deposit ratio is the total loans of a bank divided by its total deposits as on March 31, 2001.

- Capital ratio is the book value of shareholder equity plus reserves divided by total assets as on March 31, 2001.

- $\quad$ Deposit growth $(t-1)$ is $\log \left(\mathrm{D}_{\mathrm{t}-1} / \mathrm{D}_{\mathrm{t}-2}\right)$ where $\mathrm{D}_{\mathrm{t}-1}$ is the level of deposits as on March 31,2001 , and $\mathrm{D}_{\mathrm{t}-2}$ is the level of deposits as on March 31, 2000.

- Deposit growth immediate is $\log \left(\mathrm{D}_{\mathrm{t}-1} / \mathrm{D}_{\mathrm{t}-2}\right)$ where $\mathrm{D}_{\mathrm{t}-1}$ is the level of deposits as on March 31 , 2001, and $\mathrm{D}_{\mathrm{t}-2}$ is the level of deposits as on December 31, 2000.

- Deposit growth before crisis is $\log \left(\mathrm{D}_{\mathrm{t}-1} / \mathrm{D}_{\mathrm{t}-2}\right)$ where $\mathrm{D}_{\mathrm{t}-1}$ is the level of deposits as on December 31 , 2000, and $\mathrm{D}_{\mathrm{t}-2}$ is the level of deposits as on March 31, 2000.

- Correspondent relationship is a dummy variable that equals 1 for banks that a have correspondent banking relationship with the failed bank.

- Distance refers to the physical distance (in $\mathrm{Km}$ ) between the headquarters of a bank and the headquarters of the failed bank.

- Interbank borrowing is the ratio of deposits held by other cooperative banks to total deposits as on March 31, 2001.

- Other interbank lending is the ratio of deposits held in other cooperative banks to total assets as on March 31, 2001.

- Dummy other interbank lending, which is equal to 1 for banks that overall lend in the interbank market (excluding lending to the failed bank) as on March 31, 2001, and zero otherwise.

- Deposit rate change is defined as ( $\mathrm{DR}_{\mathrm{t}}-\mathrm{DR}{ }_{\mathrm{t}-1}$ )/DR ${ }_{\mathrm{t}-1}$ where $\mathrm{DR}_{\mathrm{t}}$ is the deposit rate (offered to depositors for a deposit of 1-year maturity) prevailing as on March 31, 2002, and $\mathrm{DR}_{\mathrm{t}-1}$ is deposit rate prevailing as on March 31, 2001.

- Deposit rate 2001 is the rate prevailing as on March 31, 2001, offered to depositors for a deposit of 1year maturity. 
- Information release is a dummy variable that takes the value of 1 if a bank released information on its exposure with the failed bank in its annual report for the year 2001 (the annual report is normally released between July and December).

- \# of depositors is the number of depositors in the bank as on March 31, 2000.

- Credit-to-deposit ratio 2000 is the total loans of a bank divided by its total deposits as on March 31, 2000.

- Capital ratio 2000 is the book value of shareholder equity plus reserves divided by total assets as on March 31, 2000.

- $\quad$ Return on assets 2000 is the profits of the bank divided by its total assets as on March 31, 2000.

- Loan growth is $\log \left(\mathrm{L}_{\mathrm{t}} / \mathrm{L}_{\mathrm{t}-1}\right)$ where $\mathrm{L}_{\mathrm{t}}$ is the level of loans as on December 31,2001 , and $\mathrm{L}_{\mathrm{t}-1}$ is the level of loans as on March 31, 2001.

- Future Loan growth is $\log \left(\mathrm{L}_{\mathrm{t}} / \mathrm{L}_{\mathrm{t}-1}\right)$ where $\mathrm{L}_{\mathrm{t}}$ is the level of loans as on March 31, 2002, and $\mathrm{L}_{\mathrm{t}-1}$ is the level of loans as on December 31, 2001.

- Profit growth is $\log \left(\mathrm{P}_{\mathrm{t}} / \mathrm{P}_{\mathrm{t}-1}\right)$ where $\mathrm{P}_{\mathrm{t}}$ is the level of profits as on March 31, 2002, and $\mathrm{P}_{\mathrm{t}-1}$ is the level of profits as on March 31, 2001.

- Credit deposit ratio growth is defined as $\log \left(\mathrm{CD}_{t} / \mathrm{CD}_{\mathrm{t}-1}\right)$ where $\mathrm{CD}_{\mathrm{t}}$ is the credit-deposit ratio as on December 31, 2001, and $\mathrm{CD}_{\mathrm{t}-1}$ is the credit-deposit ratio as on March 31, 2001.

- Avg District Exposure of other banks is defined as the average exposure of other banks in the district.

- \# of other banks is the number of other banks in the district. 


\section{References}

Acharya, V. and T. Yorulmazer. 2007b. Cash-in-the-Market Pricing and Optimal Resolution of Bank Failures. Review of Financial Studies, forthcoming.

Acharya, V., and T. Yorulmazer. 2007a. Too Many to Fail: An Analysis of TimeInconsistency in Bank Closure Policies. Journal of Financial Intermediation 16:1-31.

Aghion, P., P. Bolton, and M. Dewatripont. 2000. Contagious Bank Failures in a Free Banking System. European Economic Review 44:713-718.

Aharony, J., and I. Swary. 1983. Contagion Effects of Bank Failures: Evidence from Capital Markets. Journal of Business 56:305-322.

Aharony, J., and I. Swary. 1996. Additional Evidence on the Information-Based Contagion Effects of Bank Failures. Journal of Banking and Finance 20:57-69.

Allen, F., and D. Gale. 1998. Optimal Financial Crises. Journal of Finance 53:1245-1284.

Allen, F., and D. Gale. 2000. Financial Contagion. Journal of Political Economy 108:1-33.

Allen, F., and D. Gale. 2007. Understanding Financial Crises. Oxford: Oxford University Press.

Bandt, O. de, P. Hartmann, and J.-L. Peydró. 2009. Systemic Risk in Banking: An Update. In A. N. Berger, P. Molyneux, and J. Wilson, eds., The Oxford Handbook of Banking. Oxford: Oxford University Press.

Banerjee, A., and E. Duflo. 2002. Do Firms Want to Borrow More? Testing Credit Constraints Using a Directed Lending Program. Working paper, MIT.

Barth, J., G. Caprio, and R. Levine. 2004. Bank Regulation and Supervision: What Works best? Journal of Financial Intermediation 13:205-248.

Bernanke, B. 1983. Non-monetary Effects of the Financial Crisis in Propagation of the Great Depression. American Economic Review 73:257-76.

Bhattacharya, S., and P. Fulghieri. 1994. Uncertain Liquidity and Interbank Contracting. Economics Letters 44:287-294.

Bhattacharya, S., and D. Gale. 1987. Preference Shocks, Liquidity, and Central Bank Policy. In W. Barnett and K. Singleton, eds., New Approaches to Monetary Economics. Cambridge: Cambridge University Press.

Broaddus, A. 1993. Central Banking: Then and Now. Federal Reserve Bank of Richmond Economic Quarterly 79:1-11.

Brusco, S., and F. Castiglionesi. 2005. Liquidity Coinsurance, Moral Hazard and Financial Contagion. Journal of Finance, forthcoming.

Calomiris, C., and G. Gorton. 1991. The Origins of Banking Panics: Models, Facts, and Bank Regulation. In Financial Markets and Financial Crises, ed. G. Hubbard. Chicago: University of Chicago Press.

Calomiris, C., and C. Kahn. 1991. The Role of Demandable Debt in Structuring Optimal Banking Arrangements. American Economic Review 81:497-513.

Calomiris, C., and J. Mason. 1997. Contagion and Bank Failures During the Great Depression: The June 1932 Chicago Banking Panic. American Economic Review 87:863883. 
Calomiris, C., and J. Mason. 2003a. Consequences of Bank Distress During the Great Depression. American Economic Review 93:937-947.

Calomiris, C., and J. Mason. 2003b. Fundamentals, Panics and Bank Distress During the Depression. American Economic Review 93:1615-1647.

Chari, V., and R. Jagannathan. 1988. Banking Panics, Information, and Rational Expectations Equilibrium. Journal of Finance 43:749-763.

Cifuentes, R., G. Ferrucci, and H. Shin. 2005. Liquidity Risk and Contagion. Forthcoming in the EEA conference volume of Journal of the European Economic Association.

Dasgupta, A. 2004. Financial Contagion Through Capital Connections: A Model of the Origin and Spread of Bank Panics. Journal of European Economic Association, forthcoming.

Degryse, H., and G. Nguyen. 2005. Interbank Exposures: An Empirical Examination of Systemic Risk in the Belgian Banking System. Working paper, Tilburg.

Dell'Ariccia, G., E. Detragiache, and R. Rajan. 2005. The Real Effect of Banking Crises. CEPR Discussion Papers.

Demirguç-Kunt, A., B. Karacaovali, and L. Laeven. 2005. Deposit Insurance Around the World: A Comprehensive Database. Working paper, World Bank.

Diamond, D., and P. Dybvig. 1983. Bank Runs, Deposit Insurance, and Liquidity. Journal of Political Economy 91:401-419.

Diamond, D., and R. Rajan. 2005. Liquidity Shortages and Banking Crises. Journal of Finance 60:615-647.

Elsinger, H., A. Lehar, and M. Summer. 2003. Risk Assessment for Banking Systems. Management Science, forthcoming.

Flannery, M. 1996. Financial Crises, Payment System Problems, and Discount Window Lending. Journal of Money, Credit and Banking 28:804-824.

Freixas, X., B. Parigi, and J. C. Rochet. 2000. Systemic Risk, Interbank Relations, and Liquidity Provision by the Central Bank. Journal of Money, Credit,and Banking 32:611638.

Friedman, M., and A. Schwartz. 1963. A Monetary History of the United States. Princeton, NJ: Princeton University Press.

Furfine, C. 2002. The Interbank Market During a Crisis. European Economic Review 46:809-820.

Furfine, C. 2003. Interbank Exposures: Quantifying the Risk of Contagion. Journal of Money, Credit and Banking 35:111-128.

Gan, J. 2007. The Real Effects of Asset Market Bubbles: Loan and Firm-Level Evidence of a Lending Channel. Review of Financial Studies 20:1941-1973.

Goldstein, I., and A. Pauzner. 2005. Demand Deposit Contracts and the Probability of Bank Runs. Journal of Finance 60:1293-1327.

Goodfriend, M., and R. King. 1988. Financial Deregulation, Monetary Policy, and Central Banking. In Restructuring Banking and Financial Services in America. AEI Studies 481. 216-253. 
Goodhart, C., and D. Schoenmaker. 1995. Institutional Separation Between Supervisory and Monetary Agencies. In Goodhart ed., The Central Bank and the Financial System. New York: Macmillan.

Gorton, G. 1988. Banking Panics and Business Cycles. Oxford Economic Papers 40:751781.

Gropp, R., M. Lo Duca, and J. Vesala. 2005. Bank Contagion in Europe. Working paper, European Central Bank.

Hartmann, P., S. Straetmans, and C. De Vries. 2005. Banking System Stability: A CrossAtlantic Perspective. Working paper, NBER.

Holmström, B., and J. Tirole. 1998. Private and Public Provision of Liquidity, Journal of Political Economy 106: 1-40.

Humphrey, D. 1986. Payments Finality and Risk of Settlement Failure. In A. Saunders and L. White, eds., Technology and the Regulation of Financial Markets: Securities, Futures and Banking. CITY: Lexington Books.

Ioannidou, V., S. Ongena, and J.-L. Peydró. 2008. Monetary Policy, Risk-Taking and Pricing: Evidence from a Quasi-natural Experiment. Mimeo, CentER - Tilburg University.

Iyer, R., and J.-L. Peydró. 2005. How Does a Shock Propagate? A Model of Contagion in the Interbank Market due to Financial Linkages. Working paper, University of Amsterdam.

Iyer, R., and M. Puri. 2007. Understanding Bank Runs: The Importance of Depositor-Bank Relationships and Networks. Working paper, University of Amsterdam.

Jacklin, C., and S. Bhattacharya. 1988. Distinguishing Panics and Information-Based Bank Runs: Welfare and Policy Implications. Journal of Political Economy 96:568-592.

Jayanti, S., and A.-M. Whyte. 1996. Global Contagion Effects of the Continental Illinois Failure. Journal of International Financial Markets, Institutions and Money 6:87-99.

Jiménez, G., S. Ongena, J.-L. Peydró, and J. Saurina. 2008. Hazardous Times for Monetary Policy: What Do Twenty-three Million Bank Loans Say About the Effects of Monetary Policy on Credit Risk? CEPR working paper.

Jiménez, G., S. Ongena, J.-L. Peydró, and J. Saurina. 2009. The Impact of Economic and Monetary Conditions on Loan Supply: Identifying Simultaneously Firm and Bank Balance Sheet Channels. ECB Mimeo.

Kaminsky, G., and C. Reinhart. 2000. On Crises, Contagion and Confusion. Journal of International Economics 51:145-168.

Kaufman, G. 1994. Bank Contagion: A Review of the Theory and Evidence. Journal of Financial Services Research 8:123-150.

Kelly, M., and C. O’Grada. 2000. Market Contagion: Evidence from the Panics of 1854 and 1857. American Economic Review 90:1110-1124.

Khwaja, A., and A. Mian. 2007. Tracing the Impact of Bank Liquidity Shocks: Evidence from an Emerging Market. American Economic Review, forthcoming.

Kho, B.-C., L. Dong, and R. Stulz. 2000. U.S. Banks, Crises, and Bailouts: From Mexico to LTCM. American Economic Review 90:28-31.

Lang, L., and R. Stulz. 1992. Contagion and Competitive Intra-industry Effects of Bankruptcy Announcements. Journal of Financial Economics 32:45-60. 
Leitner, Y. 2005. Financial Networks: Contagion, Commitments and Private-Sector Bailouts. Journal of Finance, forthcoming.

Maddaloni, A., and J.-L. Peydró. 2009. Bank Risk-Taking, Securitization, Supervision and Low Interest Rates: Evidence from Lending Standards. ECB Mimeo.

Martinez Peria, M. Soledad, and S. Schmukler. 2001. Do Depositors Punish Banks for Bad Behavior? Market Discipline, Deposit Insurance, and Banking Crises. Journal of Finance 56:1029-1051.

Mian, A. 2006. Distance Constraints: The Limits of Foreign Lending in Poor Economies. Journal of Finance 61:1465-1505.

Morck, R., A. Shleifer, and R. Vishny. 1988. Management Ownership and Market Valuation. Journal of Financial Economics 20:293-315.

Okuno-Fujiwara, M., A. Postlewaite, and C. Suzumura. 1990. Strategic Information Revelation. Review of Economic Studies 57:25-47.

Ongena, S., D. Smith, and D. Michalsen. 2003. Firms and Their Distressed Banks: Lessons from the Norwegian Banking Crisis (1988-1991), Journal of Financial Economics 67:81112.

Rajan, R. 2006. Has Finance Made the World Riskier? European Financial Management 12:499-533.

Rochet, J. C., and J. Tirole. 1996. Interbank Lending and Systemic Risk, Journal of Money, Credit, and Banking 28:733-762.

Rochet, J. C., and X. Vives. 2004. Coordination Failures and the Lender of Last Resort: Was Bagehot Right After All? Journal of the European Economic Association, forthcoming.

Saunders, A., and B. Wilson. 1996. Contagious Bank Runs: Evidence from the 1929-1933 Period. Journal of Financial Intermediation 5:409-423.

Schumacher, L. 2000. Bank Runs and Currency Run in a System Without a Safety Net: Argentina and the “Tequila” Shock. Journal of Monetary Economics 46:257-277.

Slovin, M., M. Sushka, and J. Polonchek. 1993. The Value of Bank Durability: Borrowers as Bank Stakeholders. Journal of Finance 48:247-266.

Staiger, D., and J. H. Stock. 1997. Instrumental Variables Regression with Weak Instruments. Econometrica 65:557-586.

Swary, I. 1986. Stock Market Reaction to Regulatory Action in the Continental Illinois Crisis. Journal of Business 59:451-473.

Upper, C. 2006. Contagion due to Interbank Credit Exposures: What Do We Know, Why Do We Know It, and What Should We Know? Mimeo, BIS.

Upper, C., and A. Worms. 2004. Estimating Bilateral Exposures in the German Interbank Market: Is There a Danger of Contagion. European Economic Review 48:827-849.

Vives, X. 2004. Complementarities and Games: New Developments. Journal of Economic Literature, forthcoming. 
Table 1

\section{Summary statistics}

This table provides summary statistics for the banks in the sample. Deposit growth is $\log \left(\mathrm{D}_{t} / \mathrm{D}_{\mathrm{t}-1}\right)$ where $\mathrm{D}_{\mathrm{t}}$ is the level of deposits as on December 31, 2001, and $\mathrm{D}_{\mathrm{t}-1}$ is the level of deposits as on March 31, 2001. Large deposit withdrawals is a dummy variable that takes the value of 1 if deposit growth is lower than or equal to $-12.75 \%$ (which implies that $20 \%$ of the observations exhibit large deposit withdrawals). Exposure is the credit outstanding of a bank with the failed bank divided by its total assets as on March 13, 2001. Return on assets is the profits of the bank divided by its total assets. Size is the log of total assets of the bank. Media is a dummy variable that takes the value of 1 if a report about the bank appeared in newspapers in the period between March 13 and 31, 2001. Weak is a dummy variable that takes the value 1 when a bank is classified as weak by the central bank. Credit-to-deposit ratio is the total loans of a bank divided by its total deposits. Capital ratio is the book value of shareholder equity plus reserves divided by total assets. Deposit growth $(t-1)$ is $\log \left(\mathrm{D}_{\mathrm{t}-1} / \mathrm{D}_{\mathrm{t}-2}\right)$ where $\mathrm{D}_{\mathrm{t}-1}$ is the level of deposits as on March 31, 2001, and $\mathrm{D}_{\mathrm{t}-2}$ is the level of deposits as on March 31, 2000. Correspondent relationship is a dummy variable that equals 1 for banks that a have correspondent banking relationship with the failed bank. Distance refers to the physical distance (in Km) between the headquarters of a bank and the headquarters of the failed bank. Interbank borrowing is the ratio of deposits held by other cooperative banks to total deposits as on March 31, 2001. Other interbank lending is the ratio of deposits held in other cooperative banks to total assets as on March 31, 2001. Deposit rate change is defined as $\left(\mathrm{DR}_{\mathrm{t}}-\mathrm{DR}_{\mathrm{t}-1}\right) / \mathrm{DR}_{\mathrm{t}-1}$ where $\mathrm{DR}_{\mathrm{t}}$ is the deposit rate (offered to depositors for a deposit of 1-year maturity) prevailing as on March 31, 2002, and $\mathrm{DR}_{\mathrm{t}-1}$ is the deposit rate prevailing as on March 31, 2001. Deposit rate 2001 is the rate prevailing as on March 31, 2001, offered to depositors for a deposit of 1-year maturity. Information release is a dummy that takes the value of 1 if the bank released information on its exposure with the failed bank in the year 2001 annual report. Loan growth is defined as $\log \left(\mathrm{L}_{t} / \mathrm{L}_{\mathrm{t}-1}\right)$ where $\mathrm{L}_{\mathrm{t}}$ is the level of loans as on December 31, 2001, and $\mathrm{L}_{t-1}$ is the level of loans as on March 31, 2001. Profit growth is $\log \left(\mathrm{P}_{\mathrm{t}} / \mathrm{P}_{\mathrm{t}-1}\right)$ where $\mathrm{P}_{t}$ is the level of profits as on March 31, 2002, and $\mathrm{P}_{\mathrm{t}-1}$ is the level of profits as on March 31, 2001. \# of depositors is the number of depositors in the bank as on March 31, 2000. All balance sheet variables are measured as on March 31, 2001, unless stated. Dummy variables take the value of 0 otherwise.

\begin{tabular}{|c|c|c|c|c|c|c|}
\hline & Mean & Median & $\begin{array}{c}\text { Standard } \\
\text { Deviation }\end{array}$ & Min & Max & $\mathrm{N}$ \\
\hline Deposit growth & -0.049 & -0.039 & 0.133 & -0.506 & 0.508 & 142 \\
\hline Large deposit withdrawals & 0.197 & 0 & 0.399 & 0 & 1 & 142 \\
\hline Exposure & 0.032 & 0.005 & 0.051 & 0 & 0.235 & 142 \\
\hline Return on assets & 0.010 & 0.009 & 0.008 & -0.036 & 0.040 & 142 \\
\hline Size & 9.165 & 9.097 & 0.775 & 7.993 & 12.088 & 142 \\
\hline Media & 0.070 & 0 & 0.256 & 0 & 1 & 142 \\
\hline Weak & 0.091 & 0 & 0.289 & 0 & 1 & 142 \\
\hline Credit-to-deposit ratio & 0.636 & 0.624 & 0.160 & 0.262 & 1.044 & 142 \\
\hline Capital ratio & 0.112 & 0.107 & 0.039 & 0.039 & 0.291 & 142 \\
\hline Deposit growth $(t-1)$ & 0.141 & 0.128 & 0.128 & -0.215 & 0.586 & 142 \\
\hline Correspondent relationship & 0.464 & 0 & 0.500 & 0 & 1 & 142 \\
\hline Distance & 121 & 79 & 98 & 0 & 345 & 142 \\
\hline Interbank borrowing & 0.008 & 0 & 0.025 & 0 & 0.155 & 124 \\
\hline Other interbank lending & 0.029 & 0.002 & 0.053 & 0 & 0.258 & 121 \\
\hline Deposit rate change & 0.044 & 0 & 0.103 & -0.251 & 0.310 & 70 \\
\hline Deposit rate 2001 & 0.087 & 0.09 & 0.012 & 0.055 & 0.12 & 84 \\
\hline Information release & 0.316 & 0 & 0.466 & 0 & 1 & 142 \\
\hline Loan growth & -0.055 & -0.042 & 0.144 & -0.518 & 0.431 & 129 \\
\hline Profit growth & -0.104 & 0.034 & 0.503 & -1.888 & 1.863 & 128 \\
\hline \# of depositors & 45,897 & 40,013 & 24,822 & 8,000 & 139,611 & 121 \\
\hline
\end{tabular}




\section{Table 2}

\section{Ex ante differences in bank fundamentals between banks with high versus low exposure}

This table presents the results of a two-sided $t$-test of the mean of bank fundamentals between banks with high levels of exposure versus banks with low level of exposure. To distinguish between high vs. low exposure, in Table 4A, high exposure refers to banks with the exposure higher than or equal to $9.21 \%$ (average plus one standard deviation of exposure if exposure is positive), whereas Non-high exposure refers to banks with exposure lower than $9.21 \%$. By contrast, Table 4B uses banks with positive exposure versus banks with zero exposure. The bank fundamentals are the following: (i) Return on assets is the profits of the bank divided by its total assets; (ii) Size is the log of total assets of the bank, and (iii) Deposit rate is the rate prevailing as on March 31, 2001, offered to depositors for a deposit of 1-year maturity. All balance sheet variables are measured as on March 31, 2001 , unless stated. *, **, *** denote statistical significance at the $10 \%, 5 \%$, and $1 \%$ levels, respectively.
Return on assets
Size
Deposit rate

(1) (2) (3)

\section{Table 4a}

\section{Non-High exposure}

Mean

0.0105

9.1734

0.0872

Standard error

(0.0007)

(0.0729)

(0.0014)

$N$

122

122

68

\section{High exposure}

Mean

0.0114

9.1142

0.0896

Standard error

(0.0016)

$(0.1280)$

(0.0032)

$N$

20

20

16

Tests for differences between means ( $p$-values)

Low vs. High exposure

\section{Table 4b}

Zero exposure

Mean
Standard error

0.0115

\section{Positive exposure}

Mean

Tests for differences between means ( $p$-values) 
Table 3

\section{Effect of exposure on deposit growth}

This table presents results of OLS regressions where the dependent variable is deposit growth. Deposit growth is $\log \left(\mathrm{D}_{t} / \mathrm{D}_{\mathrm{t}-1}\right)$ where $\mathrm{D}_{\mathrm{t}}$ is the level of deposits as on December 31, 2001, and $\mathrm{D}_{\mathrm{t}-1}$ is the level of deposits as on March 31, 2001. Exposure is the credit outstanding of a bank with the failed bank divided by its total assets as on March 13, 2001. Dummy high exposure is a dummy variable that takes the value of 1 if exposure is higher than or equal to 9.21\% (average plus one standard deviation of exposure if exposure is positive). Dummy zero exposure is a dummy variable that takes the value of 1 if exposure is equal to $0 \%$. Other interbank lending is the ratio of deposits held in other cooperative banks to total assets as on March 31, 2001. Size is the log of total assets of the bank. Return on assets is the profits of the bank divided by its total assets. Media is a dummy variable that takes the value of 1 if a report about the bank appeared in newspapers in the period between March 13 and 31, March 2001. Weak is a dummy variable that takes the value 1 when a bank is classified as weak by the central bank. Credit-to-deposit ratio is the total loans of a bank divided by its total deposits. Capital ratio is the book value of shareholder equity plus reserves divided by total assets. Correspondent relationship is a dummy variable that equals 1 for banks that a have correspondent banking relationship with the failed bank. Distance refers to the physical distance (in $\mathrm{Km}$ ) between the headquarters of a bank and the headquarters of the failed bank. Deposit growth $(t-1)$ is $\log \left(\mathrm{D}_{t-1} / \mathrm{D}_{t-2}\right)$ where $\mathrm{D}_{t-1}$ is the level of deposits as on March 31 , 2001, and $\mathrm{D}_{\mathrm{t}-2}$ is the level of deposits as on March 31, 2000. District controls are dummy variables that take the value of 1 if the bank is headquartered in a district. There are 16 different districts in our sample. All balance sheet variables are measured as on March 31, 2001, unless stated. Dummy variables take the value of 0 otherwise. Heteroskedasticity-robust standard errors are in parentheses. Unless otherwise stated, regressions are estimated with constants, but the coefficients are not reported. $*$, **, *** denote statistical significance at the $10 \%, 5 \%$, and $1 \%$ levels, respectively.

\begin{tabular}{|c|c|c|c|c|c|}
\hline & \multicolumn{5}{|c|}{$\begin{array}{c}\text { OLS } \\
\text { Deposit } \\
\text { growth }\end{array}$} \\
\hline & $(1)$ & $(2)$ & $(3)$ & $(4)$ & $(5)$ \\
\hline Exposure & $\begin{array}{c}-0.712 * * * \\
(0.262)\end{array}$ & $\begin{array}{c}-0.670 * * * \\
(0.231)\end{array}$ & $\begin{array}{c}-0.636^{* *} \\
(0.317)\end{array}$ & & \\
\hline Dummy high exposure & & & & & $\begin{array}{c}-0.086^{* *} \\
(0.038)\end{array}$ \\
\hline Dummy zero exposure & & & & $\begin{array}{l}0.062 * * \\
(0.031)\end{array}$ & \\
\hline Other interbank lending & & & $\begin{array}{r}-0.114 \\
(0.150)\end{array}$ & & \\
\hline Size & $\begin{array}{r}-0.015 \\
\quad(0.016)\end{array}$ & $\begin{array}{r}-0.018 \\
(0.013)\end{array}$ & $\begin{array}{r}-0.015 \\
(0.017)\end{array}$ & $\begin{array}{r}-0.017 \\
(0.015)\end{array}$ & $\begin{array}{r}-0.018 \\
(0.016)\end{array}$ \\
\hline Return on assets & $\begin{array}{l}3.333 * * \\
(1.350)\end{array}$ & $\begin{array}{l}1.776 * \\
(1.053)\end{array}$ & $\begin{array}{l}3.318 * * \\
(1.478)\end{array}$ & $\begin{array}{l}2.655^{*} \\
(1.392)\end{array}$ & $\begin{array}{l}3.254^{* *} \\
(1.363)\end{array}$ \\
\hline Media & $\begin{array}{c}-0.193 * * * \\
(0.047)\end{array}$ & $\begin{array}{c}-0.163 * * * \\
(0.045)\end{array}$ & $\begin{array}{c}-0.177 * * * \\
(0.051)\end{array}$ & $\begin{array}{c}-0.189 * * * \\
(0.048)\end{array}$ & $\begin{array}{c}-0.193^{* * *} \\
(0.045)\end{array}$ \\
\hline Weak & $\begin{array}{c}-0.069 * \\
(0.038)\end{array}$ & $\begin{array}{c}-0.068 * \\
(0.037)\end{array}$ & $\begin{array}{l}-0.071 \\
(0.045)\end{array}$ & $\begin{array}{r}-0.050 \\
(0.040)\end{array}$ & $\begin{array}{l}-0.061 \\
(0.037)\end{array}$ \\
\hline Credit-to-deposit ratio & $\begin{array}{c}-0.168 * * \\
(0.081)\end{array}$ & $\begin{array}{c}-0.154 * \\
(0.079)\end{array}$ & $\begin{array}{c}-0.131^{* *} \\
(0.075)\end{array}$ & $\begin{array}{l}-0.110 \\
(0.071)\end{array}$ & $\begin{array}{c}-0.181 * * \\
(0.086)\end{array}$ \\
\hline Capital ratio & $\begin{array}{r}-0.111 \\
\quad(0.246)\end{array}$ & $\begin{array}{l}0.018 \\
(0.244)\end{array}$ & $\begin{array}{l}0.082 \\
(0.256)\end{array}$ & $\begin{array}{l}-0.157 \\
(0.249)\end{array}$ & $\begin{array}{l}-0.041 \\
(0.251)\end{array}$ \\
\hline Correspondent relationship & & $\begin{array}{l}0.016 \\
(0.018)\end{array}$ & $\begin{array}{l}0.023 \\
(0.021)\end{array}$ & $\begin{array}{l}0.020 \\
(0.020)\end{array}$ & $\begin{array}{l}0.018 \\
(0.019)\end{array}$ \\
\hline Distance & & $\begin{array}{r}-0.000 \\
(0.000)\end{array}$ & & & \\
\hline Deposit growth $(t-1)$ & & $\begin{array}{c}0.217 * * \\
(0.101)\end{array}$ & & & \\
\hline Constant & $\begin{array}{c}0.222 \\
0.185 \\
\end{array}$ & $\begin{array}{l}0.210 \\
(0.148) \\
\end{array}$ & $\begin{array}{l}0.164 \\
(0.172) \\
\end{array}$ & $\begin{array}{l}0.168 \\
(0.175) \\
\end{array}$ & $\begin{array}{l}0.231 \\
(0.185) \\
\end{array}$ \\
\hline $\begin{array}{l}\text { District controls } \\
\text { Number of banks }\end{array}$ & $\begin{array}{l}\text { yes } \\
142\end{array}$ & $\begin{array}{l}\text { no } \\
142\end{array}$ & $\begin{array}{l}\text { yes } \\
121\end{array}$ & $\begin{array}{l}\text { yes } \\
142\end{array}$ & $\begin{array}{l}\text { yes } \\
142\end{array}$ \\
\hline Adj./pseudo $R$-squared & 0.283 & 0.348 & 0.326 & 0.234 & 0.255 \\
\hline
\end{tabular}




\section{Table 4 \\ The effect of exposure on large deposit withdrawals}

This table presents results of probits where the dependent variable is large deposit withdrawals. Large deposit withdrawals is a dummy variable that takes the value of 1 if deposit growth is lower than or equal to $-12.75 \%$ (which implies that $20 \%$ of the observations exhibit large deposit withdrawals). Exposure is the credit outstanding of a bank with the failed bank divided by its total assets as on March 13, 2001. Dummy high exposure is a dummy variable that takes the value of 1 if exposure is higher than or equal to $9.21 \%$ (average plus one standard deviation of exposure if exposure is positive). Dummy zero exposure is a dummy variable that takes the value of 1 if exposure is equal to $0 \%$. Other interbank lending is the ratio of deposits held in other cooperative banks to total assets as on March 31, 2001. Size is the log of total assets of the bank. Return on assets is the profits of the bank divided by its total assets. Media is a dummy variable that takes the value of 1 if a report about the bank appeared in newspapers in the period between March 13 and 31, March 2001. Weak is a dummy variable that takes the value 1 when a bank is classified as weak by the central bank. Credit-to-deposit ratio is the total loans of a bank divided by its total deposits. Capital ratio is the book value of shareholder equity plus reserves divided by total assets. Correspondent relationship is a dummy variable that equals 1 for banks that a have correspondent banking relationship with the failed bank. Distance refers to the physical distance (in $\mathrm{Km}$ ) between the headquarters of a bank and the headquarters of the failed bank. Deposit growth ( $t-1)$ is log $\left(\mathrm{D}_{\mathrm{t}-1} / \mathrm{D}_{\mathrm{t}-2}\right)$ where $\mathrm{D}_{\mathrm{t}-1}$ is the level of deposits as on March 31, 2001, and $\mathrm{D}_{\mathrm{t}-2}$ is the level of deposits as on March 31, 2000. District controls are dummy variables that take the value of 1 if the bank is headquartered in a district. There are 16 different districts in our sample. All balance sheet variables are measured as on March 31, 2001, unless stated. Dummy variables take the value of 0 otherwise. Heteroskedasticity-robust standard errors are in parentheses. In column 2, 3, 4, and 5 standard errors are clustered at the district level. Unless otherwise stated, regressions are estimated with constants, but the coefficients are not reported. *, **, *** denote statistical significance at the $10 \%, 5 \%$, and $1 \%$ levels, respectively.

\begin{tabular}{|c|c|c|c|c|c|}
\hline & \multicolumn{5}{|c|}{$\begin{array}{l}\text { Probit } \\
\text { Large deposit } \\
\text { withdrawals }\end{array}$} \\
\hline & $(1)$ & $(2)$ & (3) & $(4)$ & $(5)$ \\
\hline Exposure & $\begin{array}{l}10.328^{* * *} \\
(3.726)\end{array}$ & $\begin{array}{l}8.357 * * * \\
(2.938)\end{array}$ & $\begin{array}{l}9.624 * * * \\
(3.455)\end{array}$ & & \\
\hline Dummy high exposure & & & & $\begin{array}{l}1.068 * * * \\
(0.387)\end{array}$ & \\
\hline Dummy zero exposure & & & & & $\begin{array}{c}-1.350 * * * \\
(0.226)\end{array}$ \\
\hline Other interbank lending & & & $\begin{array}{l}0.770 \\
(1.948)\end{array}$ & & \\
\hline Size & $\begin{array}{l}-0.095 \\
(0.237)\end{array}$ & $\begin{array}{l}-0.048 \\
\quad(0.168)\end{array}$ & $\begin{array}{c}0.016 \\
(0.187)\end{array}$ & $\begin{array}{l}-0.041 \\
(0.152)\end{array}$ & $\begin{array}{r}-0.050 \\
(0.139)\end{array}$ \\
\hline Return on assets & $\begin{array}{c}-39.193 * \\
(20.391)\end{array}$ & $\begin{array}{c}-33.977 * * \\
(15.863)\end{array}$ & $\begin{array}{c}-36.013 * \\
(20.415)\end{array}$ & $\begin{array}{c}-32.098 * * \\
(16.250)\end{array}$ & $\begin{array}{r}-25.013 \\
(18.681)\end{array}$ \\
\hline Media & $\begin{array}{l}1.352^{* *} \\
(0.619)\end{array}$ & $\begin{array}{l}1.503^{* * *} \\
(0.274)\end{array}$ & $\begin{array}{l}1.596 * * * \\
(0.382)\end{array}$ & $\begin{array}{c}1.710 * * * \\
(0.237)\end{array}$ & $\begin{array}{c}1.836 * * * \\
(0.317)\end{array}$ \\
\hline Weak & $\begin{array}{c}1.595^{* * * *} \\
(0.513)\end{array}$ & $\begin{array}{c}0.840 * * \\
(0.346)\end{array}$ & $\begin{array}{l}0.872 * * \\
(0.815)\end{array}$ & $\begin{array}{l}0.851 * * \\
(0.363)\end{array}$ & $\begin{array}{c}0.690 * * \\
(0.287)\end{array}$ \\
\hline Credit-to-deposit ratio & $\begin{array}{l}1.305 \\
(0.957)\end{array}$ & $\begin{array}{l}1.465^{*} \\
(0.813)\end{array}$ & $\begin{array}{l}1.383 * \\
(0.815)\end{array}$ & $\begin{array}{l}1.170 \\
(0.820)\end{array}$ & $\begin{array}{r}-0.119 \\
(0.715)\end{array}$ \\
\hline Capital ratio & $\begin{array}{l}0.154 \\
(3.995)\end{array}$ & $\begin{array}{r}-0.385 \\
(2.550)\end{array}$ & $\begin{array}{l}1.815 \\
(3.194)\end{array}$ & $\begin{array}{c}0.691 \\
(0.251)\end{array}$ & $\begin{array}{l}2.249 \\
(2.808)\end{array}$ \\
\hline Correspondent relationship & & $\begin{array}{r}-0.451 \\
\quad(0.335)\end{array}$ & $\begin{array}{l}-0.426 \\
(0.407)\end{array}$ & $\begin{array}{l}-0.286 \\
(0.297)\end{array}$ & $\begin{array}{l}-0.199 \\
(0.309)\end{array}$ \\
\hline Distance & & $\begin{array}{l}0.003^{*} \\
(0.001)\end{array}$ & $\begin{array}{l}0.002 \\
(0.001)\end{array}$ & $\begin{array}{l}0.002 \\
(0.001)\end{array}$ & $\begin{array}{l}0.002 \\
(0.001)\end{array}$ \\
\hline Deposit growth $(t-1)$ & & $\begin{array}{l}-1.871^{* * *} \\
(0.687)\end{array}$ & & & \\
\hline District controls & yes & no & no & no & no \\
\hline Number of banks & 112 & 142 & 121 & 142 & 142 \\
\hline Adj./pseudo $R$-squared & 0.314 & 0.227 & 0.240 & 0.189 & 0.174 \\
\hline
\end{tabular}


Table 5

\section{The nonlinear effect of exposure on deposit withdrawals}

Column 1 and 2 present the results of an OLS regression where the dependent variable is deposit growth. Column 3 and 4 present the results of a probit where the dependent variable is large deposit withdrawals. Deposit growth is $\log \left(\mathrm{D}_{\mathrm{t}} / \mathrm{D}_{\mathrm{t}-1}\right)$ where $\mathrm{D}_{\mathrm{t}}$ is the level of deposits as on December 31, 2001, and $\mathrm{D}_{\mathrm{t}-1}$ is the level of deposits as on March 31, 2001. Large deposit withdrawals is a dummy variable that takes the value of 1 if deposit growth is lower than or equal to $-12.75 \%$ (which implies that $20 \%$ of the observations exhibit large deposit withdrawals). High exposure is equal to exposure minus 0.0921 if exposure is greater than or equal to $9.21 \%$ and is equal to 0 if exposure is lower than $9.21 \%$ (average plus one standard deviation of exposure if exposure is positive). Medium exposure is equal to exposure minus 0.0383 if exposure is greater than or equal to $3.83 \%$ and lower than 9.21\%; it is equal to 0 if exposure is lower than 3.83\% (average of exposure if exposure is positive); and it is equal to 0.0921 if exposure is greater than or equal to $9.21 \%$. Low exposure is equal to exposure if exposure is lower than $3.83 \%$; it is equal to zero if exposure is 0 ; and it is equal to 0.0383 if exposure is greater than or equal to $3.83 \%$. Dummy zero exposure is a dummy variable that takes the value of 1 if exposure is equal to $0 \%$. All the independent variables are described in the Appendix. All balance sheet variables are measured as on March 31, 2000, unless otherwise stated. Heteroskedasticity-robust standard errors are in parentheses. In column 3 and 4 standard errors are clustered at the district level. Unless otherwise stated, regressions are estimated with constants, but the coefficients are not reported. *, **, *** denote statistical significance at the $10 \%, 5 \%$, and $1 \%$ levels, respectively.

\begin{tabular}{|c|c|c|c|c|}
\hline & $\begin{array}{l}\text { OLS } \\
\text { Deposit } \\
\text { growth }\end{array}$ & $\begin{array}{l}\text { OLS } \\
\text { Deposit } \\
\text { growth }\end{array}$ & $\begin{array}{l}\text { Probit } \\
\text { Large dep. } \\
\text { withdrawals }\end{array}$ & $\begin{array}{l}\text { Probit } \\
\text { Large dep. } \\
\text { withdrawals }\end{array}$ \\
\hline & (1) & (2) & (3) & (4) \\
\hline High exposure & $\begin{array}{l}-1.325 * * \\
(0.628)\end{array}$ & $\begin{array}{l}-1.192^{*} \\
(0.637)\end{array}$ & $\begin{array}{l}21.734^{* * * *} \\
(7.124)\end{array}$ & $\begin{array}{l}19.851^{* * *} \\
(6.820)\end{array}$ \\
\hline Medium exposure & $\begin{array}{l}-1.901^{*} \\
(1.082)\end{array}$ & $\begin{array}{l}-1.474 \\
(1.095)\end{array}$ & $\begin{array}{l}-5.873 \\
(18.090)\end{array}$ & $\begin{array}{l}-14.625 \\
(21.595)\end{array}$ \\
\hline Low exposure & $\begin{array}{l}0.615 \\
(1.364)\end{array}$ & $\begin{array}{l}1.250 \\
(1.192)\end{array}$ & $\begin{array}{l}0.371 \\
(10.903)\end{array}$ & $\begin{array}{l}-10.058 \\
(9.870)\end{array}$ \\
\hline Dummy zero exposure & & $\begin{array}{l}0.056^{*} \\
(0.033)\end{array}$ & & $\begin{array}{l}-1.332 * * * \\
(0.145)\end{array}$ \\
\hline Size & $\begin{array}{l}-0.161 \\
(0.169)\end{array}$ & $\begin{array}{l}-0.014 \\
(0.016)\end{array}$ & $\begin{array}{l}-0.049 \\
(0.145)\end{array}$ & $\begin{array}{l}-0.061 \\
(0.128)\end{array}$ \\
\hline Return on assets & $\begin{array}{l}3.260 * * \\
(1.364)\end{array}$ & $\begin{array}{l}2.857^{* *} \\
(1.414)\end{array}$ & $\begin{array}{l}-34.535^{* *} \\
(16.738)\end{array}$ & $\begin{array}{l}-28.726 \\
(18.999)\end{array}$ \\
\hline Media & $\begin{array}{l}-0.190 \text { *** } \\
(0.049)\end{array}$ & $\begin{array}{l}-0.195 * * * \\
(0.050)\end{array}$ & $\begin{array}{l}1.772 * * * \\
(0.269)\end{array}$ & $\begin{array}{l}2.073 * * * \\
(0.288)\end{array}$ \\
\hline Weak & $\begin{array}{l}-0.062 \\
(0.038)\end{array}$ & $\begin{array}{l}-0.063 \\
(0.039)\end{array}$ & $\begin{array}{l}0.883^{* *} \\
(0.361)\end{array}$ & $\begin{array}{l}0.957 * * \\
(0.381)\end{array}$ \\
\hline Credit-to-deposit ratio & $\begin{array}{l}-0.174^{* *} \\
(0.085)\end{array}$ & $\begin{array}{l}-0.154^{* *} \\
(0.077)\end{array}$ & $\begin{array}{l}1.212 \\
(0.895)\end{array}$ & $\begin{array}{l}0.820 \\
(0.926)\end{array}$ \\
\hline Capital ratio & $\begin{array}{l}-0.111 \\
(0.259)\end{array}$ & $\begin{array}{l}-0.125 \\
(0.252)\end{array}$ & $\begin{array}{l}1.028 \\
(2.707)\end{array}$ & $\begin{array}{l}0.112 \\
(3.104)\end{array}$ \\
\hline Correspondent relationship & $\begin{array}{l}0.016 \\
(0.020)\end{array}$ & $\begin{array}{l}0.027 \\
(0.020)\end{array}$ & $\begin{array}{l}-0.397 \\
(0.316)\end{array}$ & $\begin{array}{l}-0.539 \\
(0.347)\end{array}$ \\
\hline Distance & & & $\begin{array}{l}0.003^{*} \\
(0.001)\end{array}$ & $\begin{array}{l}0.002 \\
(0.001)\end{array}$ \\
\hline $\begin{array}{l}F \text { test of equality of coefficients } \\
\text { of high versus low exposure }\end{array}$ & 2.43 & $3.83 *$ & 2.45 & $4.81^{* *}$ \\
\hline District controls & yes & yes & no & no \\
\hline Number of banks & 142 & 142 & 142 & 142 \\
\hline Adj./pseudo $R$-squared & 0.260 & 0.273 & 0.252 & 0.286 \\
\hline
\end{tabular}




\section{Table 6 \\ The immediate effect of exposure on deposit growth}

This table presents results of OLS regressions where the dependent variables are Deposit growth immediate and Deposit growth before crisis. Deposit growth immediate is $\log \left(\mathrm{D}_{\mathrm{t}-1} / \mathrm{D}_{\mathrm{t}-2}\right)$ where $\mathrm{D}_{\mathrm{t}-1}$ is the level of deposits as on March 31,2001 , and $\mathrm{D}_{\mathrm{t}-2}$ is the level of deposits as on December 31, 2000. Deposit growth before crisis is $\log \left(\mathrm{D}_{t-1} / \mathrm{D}_{\mathrm{t}-2}\right)$ where $\mathrm{D}_{\mathrm{t}-1}$ is the level of deposits as on December 31, 2000, and $\mathrm{D}_{\mathrm{t}-2}$ is the level of deposits as on March 31, 2000. Exposure is the credit outstanding of a bank with the failed bank divided by its total assets as on March 13, 2001. Dummy high exposure is a dummy variable that takes the value of 1 if exposure is higher than or equal to $9.21 \%$. High exposure is equal to exposure minus 0.0921 if exposure is greater than or equal to $9.21 \%$ and is equal to 0 if exposure is lower than $9.21 \%$ (average plus one standard deviation of exposure if exposure is positive). Medium exposure is equal to exposure minus 0.0383 if exposure is greater than or equal to $3.83 \%$ and lower than 9.21\%; it is equal to 0 if exposure is lower than 3.83\% (average of exposure if exposure is positive); and it is equal to 0.0921 if exposure is greater than or equal to $9.21 \%$. Low exposure is equal to exposure if exposure is lower than $3.83 \%$; it is equal to 0 if exposure is 0 ; and it is equal to 0.0383 if exposure is greater than or equal to $3.83 \%$. All the independent variables are described in the Appendix. All balance sheet variables are measured as on March 31, 2000, unless otherwise stated. Heteroskedasticityrobust standard errors are in parentheses. Unless otherwise stated, regressions are estimated with constants, but the coefficients are not reported. *, **, *** denote statistical significance at the $10 \%, 5 \%$, and $1 \%$ levels, respectively.

\begin{tabular}{|c|c|c|c|c|}
\hline & \multicolumn{2}{|c|}{$\begin{array}{l}\text { OLS } \\
\text { Deposit growth immediate }\end{array}$} & \multirow[b]{2}{*}{ (3) } & \multirow{2}{*}{$\begin{array}{c}\text { OLS } \\
\begin{array}{c}\text { Deposit growth } \\
\text { before crisis }\end{array} \\
(4)\end{array}$} \\
\hline & (1) & $(2)$ & & \\
\hline Exposure & $\begin{array}{l}-0.184 * \\
(0.098)\end{array}$ & & & \\
\hline Dummy high exposure & & $\begin{array}{l}-0.029 * * \\
(0.013)\end{array}$ & & \\
\hline High exposure & & & $\begin{array}{l}-0.555^{* * *} \\
(0.172)\end{array}$ & $\begin{array}{l}0.046 \\
(0.218)\end{array}$ \\
\hline Medium exposure & & & $\begin{array}{l}0.232 \\
(0.550)\end{array}$ & $\begin{array}{l}-0.208 \\
(0.946)\end{array}$ \\
\hline Low exposure & & & $\begin{array}{l}0.457 \\
(0.696)\end{array}$ & $\begin{array}{l}0.255 \\
(1.022)\end{array}$ \\
\hline Media & $\begin{array}{l}-0.103^{* * *} \\
(0.029)\end{array}$ & $\begin{array}{l}-0.104 * * * \\
(0.028)\end{array}$ & $\begin{array}{l}-0.105^{* * *} \\
(0.016)\end{array}$ & $\begin{array}{l}-0.034 \\
(0.048)\end{array}$ \\
\hline Weak & $\begin{array}{l}-0.004 \\
(0.013)\end{array}$ & $\begin{array}{l}-0.003 \\
(0.013)\end{array}$ & $\begin{array}{l}-0.004 \\
(0.014)\end{array}$ & $\begin{array}{l}0.008 \\
(0.033)\end{array}$ \\
\hline Credit-to-deposit ratio 2000 & $\begin{array}{l}-0.010 \\
(0.032)\end{array}$ & $\begin{array}{l}-0.016 \\
(0.032)\end{array}$ & $\begin{array}{l}-0.020 \\
(0.033)\end{array}$ & $\begin{array}{l}0.190 * * * \\
(0.049)\end{array}$ \\
\hline Capital ratio 2000 & $\begin{array}{l}0.025 \\
(0.100)\end{array}$ & $\begin{array}{l}0.027 \\
(0.097)\end{array}$ & $\begin{array}{l}0.023 \\
(0.099)\end{array}$ & $\begin{array}{l}-0.637 * * * \\
(0.198)\end{array}$ \\
\hline Return on assets 2000 & $\begin{array}{l}0.460 \\
(0.682)\end{array}$ & $\begin{array}{l}0.496 \\
(0.672)\end{array}$ & $\begin{array}{l}0.495 \\
(0.672)\end{array}$ & $\begin{array}{l}4.022^{* * *} \\
(1.303)\end{array}$ \\
\hline Size 2000 & $\begin{array}{l}-0.005 \\
(0.006)\end{array}$ & $\begin{array}{l}-0.005 \\
(0.006)\end{array}$ & $\begin{array}{l}-0.005 \\
(0.006)\end{array}$ & $\begin{array}{l}-0.014 \\
(0.013)\end{array}$ \\
\hline Correspondent relationship & $\begin{array}{l}-0.002 \\
(0.010) \\
\end{array}$ & $\begin{array}{r}-0.002 \\
(0.010)\end{array}$ & $\begin{array}{r}-0.001 \\
(0.010)\end{array}$ & $\begin{array}{l}0.003 \\
(0.017)\end{array}$ \\
\hline District controls & yes & yes & yes & yes \\
\hline Number of banks & 131 & 131 & 131 & 131 \\
\hline Adj./pseudo $R$-squared & 0.439 & 0.441 & 0.462 & 0.246 \\
\hline
\end{tabular}




\section{Table 7 \\ Robustness}

Deposit rate change is defined as $\left(\mathrm{DR}_{\mathrm{t}}-\mathrm{DR}_{\mathrm{t}-1}\right) / \mathrm{DR}_{\mathrm{t}-1}$ where $\mathrm{DR}_{\mathrm{t}}$ is the deposit rate (offered to depositors for a deposit of 1-year maturity) prevailing as on March 31, 2002, and DR $\mathrm{t}-1$ is the deposit rate prevailing as on March 31, 2001. Information release is a dummy that takes the value of 1 if the bank released information on its exposure with the failed bank in the year 2001 annual report. In column 3, the sample is restricted to banks with information release equal to 0 . In column 4, we use an instrument for exposure. The instrument is dummy other interbank lending, which is equal to 1 for banks that overall lend in the interbank market (excluding lending to the failed bank) as on March 31, 2001, and 0 otherwise. Column 4 presents the first stage regression where the dependent variable is exposure. In column 5, we analyze the impact of the component of exposure predicted by the instrument on large deposit withdrawals. All the independent variables are described in the Appendix. All balance sheet variables are measured as on March 31, 2001, unless stated. Dummy variables take the value of 0 otherwise. Heteroskedasticity-robust standard errors are in parentheses. In column 2 and 3 standard errors are clustered at the district level. Unless otherwise stated, regressions are estimated with constants, but the coefficients are not reported. *, **, *** denote statistical significance at the $10 \%, 5 \%$, and $1 \%$ levels, respectively.

\begin{tabular}{|c|c|c|c|c|c|}
\hline & OLS & Probit & Probit & \multicolumn{2}{|c|}{ Instrumental Variable Probit } \\
\hline & $\begin{array}{l}\text { Deposit } \\
\text { rate change }\end{array}$ & $\begin{array}{l}\text { Information } \\
\text { release }\end{array}$ & $\begin{array}{l}\text { Large dep. } \\
\text { withdrawals }\end{array}$ & Exposure & $\begin{array}{l}\text { Large dep. } \\
\text { withdrawals }\end{array}$ \\
\hline & $(1)$ & $(2)$ & (3) & $(4)$ & (5) \\
\hline Exposure & $\begin{array}{l}-0.041 \\
(0.305)\end{array}$ & $\begin{array}{l}-5.659 * * \\
(2.735)\end{array}$ & $\begin{array}{l}9.207 * * * \\
(2.873)\end{array}$ & & $\begin{array}{l}18.729 * * \\
(9.531)\end{array}$ \\
\hline Dummy other interbank lending & & & & $\begin{array}{l}0.028 * * * \\
(0.008)\end{array}$ & \\
\hline Size & $\begin{array}{c}-0.034^{*} \\
(0.019)\end{array}$ & $\begin{array}{l}0.480 \\
(0.294)\end{array}$ & $\begin{array}{l}0.103 \\
(0.269)\end{array}$ & $\begin{array}{l}-0.003 \\
(0.006)\end{array}$ & $\begin{array}{l}0.002 \\
(0.191)\end{array}$ \\
\hline Return on assets & $\begin{array}{r}-1.700 \\
(1.396)\end{array}$ & $\begin{array}{l}-0.105 \\
(9.827)\end{array}$ & $\begin{array}{l}-65.515 \\
(13.592)\end{array}$ & $\begin{array}{l}-0.178 \\
(0.604)\end{array}$ & $\begin{array}{l}-34.263^{* *} \\
(16.880)\end{array}$ \\
\hline Media & $\begin{array}{l}0.095 \\
(0.064)\end{array}$ & $\begin{array}{l}-1.365^{* * *} \\
(0.418)\end{array}$ & $\begin{array}{l}1.221^{* * *} \\
(0.348)\end{array}$ & $\begin{array}{l}-0.003 \\
(0.009)\end{array}$ & $\begin{array}{l}1.478 * * * \\
(0.497)\end{array}$ \\
\hline Weak & $\begin{array}{c}-0.123^{*} \\
(0.049)\end{array}$ & $\begin{array}{l}-0.234 \\
(0.422)\end{array}$ & $\begin{array}{l}0.841^{*} \\
(0.470)\end{array}$ & $\begin{array}{l}-0.016 * * * \\
(0.005)\end{array}$ & $\begin{array}{l}0.885^{* * * *} \\
(0.285)\end{array}$ \\
\hline Credit-to-deposit ratio & $\begin{array}{l}-0.037 \\
(0.081)\end{array}$ & $\begin{array}{l}-0.617 \\
(0.772)\end{array}$ & $\begin{array}{l}1.454 * * \\
(0.635)\end{array}$ & $\begin{array}{l}-0.053^{* * *} \\
(0.019)\end{array}$ & $\begin{array}{l}1.758 * * \\
(0.839)\end{array}$ \\
\hline Capital ratio & $\begin{array}{l}0.770 \\
(0.576)\end{array}$ & $\begin{array}{l}-3.410 \\
(3.742)\end{array}$ & $\begin{array}{l}2.296 \\
(4.104)\end{array}$ & $\begin{array}{l}0.041 \\
(0.061)\end{array}$ & $\begin{array}{l}1.589 \\
(2.731)\end{array}$ \\
\hline Correspondent relationship & $\begin{array}{l}0.008 \\
(0.027)\end{array}$ & $\begin{array}{l}1.038 * * * \\
(0.201)\end{array}$ & $\begin{array}{l}-0.413 \\
(0.337)\end{array}$ & $\begin{array}{l}0.022^{* *} \\
(0.009)\end{array}$ & $\begin{array}{l}-0.564 \\
(0.466)\end{array}$ \\
\hline Deposit growth $(t-1)$ & $\begin{array}{l}0.169 \\
(0.175)\end{array}$ & & & & \\
\hline Distance & & $\begin{array}{l}-0.000 \\
(0.001) \\
\end{array}$ & $\begin{array}{l}0.001 \\
(0.001)\end{array}$ & $\begin{array}{l}0.000 \\
(0.000) \\
\end{array}$ & $\begin{array}{l}0.001 \\
(0.002)\end{array}$ \\
\hline District controls & yes & no & no & no & no \\
\hline Number of banks & 70 & 142 & 97 & 121 & 121 \\
\hline Adj./pseudo $R$-squared & 0.351 & 0.180 & 0.225 & $\begin{array}{l}\text { T-statisti } \\
\text { hypothe }\end{array}$ & $\begin{array}{l}\text { exclusion } \\
\text { s } 3.46^{* * * *}\end{array}$ \\
\hline
\end{tabular}




\section{Table 8}

\section{The effect of interbank linkages among banks (excluding the linkage with the failed bank)}

Columns 1, 2, and 5 present results of an OLS regression where the dependent variable is deposit growth. Columns 3 and 6 present results of a probit where the dependent variable is large deposit withdrawals. Column 4 presents results of an OLS regression where the dependent variable is interbank borrowing. In columns 5 and 6 , the sample is limited to banks that have zero interbank borrowing (the sample of banks that has only retail depositors). Deposit growth is $\log \left(\mathrm{D}_{t} / \mathrm{D}_{\mathrm{t}-1}\right)$ where $\mathrm{D}_{\mathrm{t}}$ is the level of deposits as on December 31, 2001, and $\mathrm{D}_{\mathrm{t}-1}$ is the level of deposits as on March 31, 2001. Large deposit withdrawals is a dummy variable that takes the value of 1 if deposit growth is lower than or equal to $-12.75 \%$ (which implies that $20 \%$ of the observations exhibit large deposit withdrawals). The main independent variables are interbank borrowing, exposure and an interaction variable of these two variables. Interbank borrowing is the ratio of deposits held by other cooperative banks to total deposits as on March 31, 2001. Exposure is the credit outstanding of a bank with the failed bank divided by its total assets as on March 13, 2001. Interbank borrowing x Exposure is the interaction of interbank borrowing and Exposure. All the independent variables are described in the Appendix. All balance sheet variables are measured as on March 31, 2001, except in column 4. Heteroskedasticity-robust standard errors are in parentheses. In columns 3 and 6 standard errors are clustered at the district level. Unless otherwise stated, regressions are estimated with constants, but the coefficients are not reported. *, **, *** denote statistical significance at the $10 \%, 5 \%$, and $1 \%$ levels, respectively.

\begin{tabular}{|c|c|c|c|c|c|c|}
\hline & $\begin{array}{c}\text { OLS } \\
\text { Deposit } \\
\text { growth }\end{array}$ & $\begin{array}{c}\text { OLS } \\
\text { Deposit } \\
\text { growth }\end{array}$ & $\begin{array}{c}\text { Probit } \\
\text { Large dep. } \\
\text { withdrawals }\end{array}$ & $\begin{array}{c}\text { OLS } \\
\text { Interbank } \\
\text { borrowing }\end{array}$ & $\begin{array}{c}\text { OLS } \\
\text { Deposit } \\
\text { growth }\end{array}$ & $\begin{array}{c}\text { Probit } \\
\text { Large dep. } \\
\text { withdrawals }\end{array}$ \\
\hline & $(1)$ & $(2)$ & ( 3 ) & $(4)$ & $(5)$ & $(6)$ \\
\hline Exposure & $\begin{array}{l}-0.676 * * \\
(0.292)\end{array}$ & $\begin{array}{c}-0.539 * \\
(0.300)\end{array}$ & $\begin{array}{l}9.642 * * * \\
(3.367)\end{array}$ & $\begin{array}{r}-0.053 \\
(0.038)\end{array}$ & $\begin{array}{c}-0.611^{*} \\
(0.320)\end{array}$ & $\begin{array}{l}9.959 * * * \\
(3.889)\end{array}$ \\
\hline Size & $\begin{array}{l}-0.007 \\
(0.017)\end{array}$ & $\begin{array}{l}-0.003 \\
(0.017)\end{array}$ & $\begin{array}{l}-0.104 \\
(0.255)\end{array}$ & & $\begin{array}{l}0.021 \\
(0.023)\end{array}$ & $\begin{array}{r}-0.269 \\
(0.308)\end{array}$ \\
\hline Return on assets & $\begin{array}{l}3.167 * * \\
(1.562)\end{array}$ & $\begin{array}{l}3.077^{*} \\
(1.586)\end{array}$ & $\begin{array}{l}-32.181^{*} \\
(18.784)\end{array}$ & & $\begin{array}{l}4.046 * * \\
(1.824)\end{array}$ & $\begin{array}{c}-33.715 * \\
(20.411)\end{array}$ \\
\hline Media & $\begin{array}{l}-0.169 * * * \\
(0.054)\end{array}$ & $\begin{array}{l}-0.172 * * * \\
(0.052)\end{array}$ & $\begin{array}{l}1.431^{* * *} \\
(0.355)\end{array}$ & $\begin{array}{l}0.022 \\
(0.017)\end{array}$ & $\begin{array}{c}-0.131 * \\
(0.078)\end{array}$ & $\begin{array}{l}0.781^{* * *} \\
(0.298)\end{array}$ \\
\hline Weak & $\begin{array}{l}-0.080 \\
(0.051)\end{array}$ & $\begin{array}{l}-0.087 \\
(0.053)\end{array}$ & $\begin{array}{l}1.088^{* * *} \\
(0.407)\end{array}$ & $\begin{array}{r}-0.004 \\
(0.007)\end{array}$ & $\begin{array}{l}-0.054 \\
(0.073)\end{array}$ & $\begin{array}{l}0.775 \\
(0.508)\end{array}$ \\
\hline Credit-to-deposit ratio & $\begin{array}{l}-0.115 \\
(0.071)\end{array}$ & $\begin{array}{l}-0.093 \\
(0.069)\end{array}$ & $\begin{array}{l}0.920 \\
(0.816)\end{array}$ & & $\begin{array}{r}-0.072 \\
(0.079)\end{array}$ & $\begin{array}{l}1.056 \\
(0.827)\end{array}$ \\
\hline Capital ratio & $\begin{array}{l}0.027 \\
(0.261)\end{array}$ & $\begin{array}{r}0.057 \\
(0.259)\end{array}$ & $\begin{array}{l}3.081 \\
(2.751)\end{array}$ & & $\begin{array}{l}-0.028 \\
(0.265)\end{array}$ & $\begin{array}{l}3.139 \\
(3.375)\end{array}$ \\
\hline Correspondent relationship & $\begin{array}{l}0.012 \\
(0.022)\end{array}$ & $\begin{array}{r}0.010 \\
(0.022)\end{array}$ & $\begin{array}{l}-0.259 \\
(0.384)\end{array}$ & & $\begin{array}{l}0.004 \\
(0.023)\end{array}$ & $\begin{array}{l}-0.205 \\
(0.382)\end{array}$ \\
\hline Interbank borrowing & $\begin{array}{l}-0.436 \\
(0.478)\end{array}$ & $\begin{array}{l}-0.004 \\
(0.403)\end{array}$ & $\begin{array}{l}6.015 \\
(3.821)\end{array}$ & & & \\
\hline Interbank borrowing x Exposure & & $\begin{array}{l}-82.330 * * * \\
(22.310)\end{array}$ & $\begin{array}{l}\text { 715.68*** } \\
(155.03)\end{array}$ & & & \\
\hline Distance & & & $\begin{array}{l}0.002 \\
(0.001)\end{array}$ & & & $\begin{array}{l}0.001 \\
(0.001)\end{array}$ \\
\hline Size 2000 & & & & $\begin{array}{c}0.009 \\
(0.004)\end{array}$ & & \\
\hline Credit-to-deposit ratio 2000 & & & & $\begin{array}{l}0.003 \\
(0.01)\end{array}$ & & \\
\hline Capital ratio 2000 & & & & $\begin{array}{r}-0.016 \\
(0.041)\end{array}$ & & \\
\hline Return on assets 2000 & & & & $\begin{array}{r}-0.037 \\
(0.253) \\
\end{array}$ & & \\
\hline District controls & yes & yes & no & yes & yes & no \\
\hline Number of banks & 124 & 124 & 124 & 123 & 96 & 96 \\
\hline Adj./pseudo $R$-squared & 0.336 & 0.380 & 0.292 & 0.150 & 0.235 & 0.173 \\
\hline
\end{tabular}




\section{Table 9}

\section{Interaction effects of exposure with bank fundamentals}

Columns 1, 2, and 5 present results of a probit where the dependent variable is large deposit withdrawals. Columns 3, 4, and 6 present results of the OLS regression where the dependent variable is deposit growth. Column 7 presents the results for the sample of banks that do not have other banks as depositors (the sample of banks that has only retail depositors). Deposit growth is $\log \left(\mathrm{D}_{\mathrm{t}} / \mathrm{D}_{\mathrm{t}-1}\right)$ where $\mathrm{D}_{\mathrm{t}}$ is the level of deposits as on December 31, 2001, and $\mathrm{D}_{\mathrm{t}-1}$ is the level of deposits as on March 31, 2001. Large deposit withdrawals is a dummy variable that takes the value of 1 if deposit growth is lower than or equal to $-12.75 \%$ (which implies that $20 \%$ of the observations exhibit large deposit withdrawals). The main independent variables are exposure and interaction variables of exposure with variables that proxy for bank fundamentals, where exposure is the credit outstanding of a bank with the failed bank divided by its total assets as on March 13, 2001. All the independent variables are described in the Appendix. All balance sheet variables are measured as on March 31, 2001, unless stated. Heteroskedasticity-robust standard errors are in parentheses. In columns 1, 2, and 5 standard errors are clustered at the district level. The coefficient for \# of depositors is scaled up by 100,000. Unless otherwise stated, regressions are estimated with constants, but the coefficients are not reported. *,**, *** denote statistical significance at the $10 \%, 5 \%$, and $1 \%$ levels, respectively.

\begin{tabular}{|c|c|c|c|c|c|c|c|}
\hline & $\begin{array}{c}\text { Probit } \\
\text { Large dep. } \\
\text { withdrawals }\end{array}$ & $\begin{array}{l}\text { Probit } \\
\text { Large dep. } \\
\text { withdrawals }\end{array}$ & $\begin{array}{l}\text { OLS } \\
\text { Deposit } \\
\text { growth }\end{array}$ & $\begin{array}{c}\text { OLS } \\
\text { Deposit } \\
\text { growth }\end{array}$ & $\begin{array}{c}\text { Probit } \\
\text { Large dep. } \\
\text { withdrawals }\end{array}$ & $\begin{array}{c}\text { OLS } \\
\text { Deposit } \\
\text { growth }\end{array}$ & $\begin{array}{l}\text { OLS } \\
\text { Deposit } \\
\text { growth }\end{array}$ \\
\hline & $(1)$ & ( 2 ) & $(3)$ & $(4)$ & $(5)$ & $(6)$ & (7) \\
\hline Exposure & $\begin{array}{l}7.620 * * \\
(3.22)\end{array}$ & $\begin{array}{l}9.57 * * \\
(4.08)\end{array}$ & $\begin{array}{l}-1.521^{* * *} \\
(0.26)\end{array}$ & $\begin{array}{l}-0.542^{*} \\
(0.27)\end{array}$ & $\begin{array}{l}99.505^{* *} \\
(46.47)\end{array}$ & $\begin{array}{l}-1.039 * * * \\
(0.22)\end{array}$ & $\begin{array}{l}-1.037 * * * \\
(0.262)\end{array}$ \\
\hline Size & $\begin{array}{l}-0.100 \\
(0.14)\end{array}$ & $\begin{array}{l}-0.515^{* *} \\
(0.25)\end{array}$ & $\begin{array}{l}0.100 * * * \\
(0.03)\end{array}$ & $\begin{array}{l}0.090^{* *} \\
(0.03)\end{array}$ & $\begin{array}{l}-0.711^{* * *} \\
(0.19)\end{array}$ & $\begin{array}{l}0.094^{* * * *} \\
(0.03)\end{array}$ & $\begin{array}{l}0.104^{* * * *} \\
(0.034)\end{array}$ \\
\hline Return on assets & $\begin{array}{l}-32.939 * * \\
(16.05)\end{array}$ & $\begin{array}{l}-63.904 * * * \\
(15.95)\end{array}$ & $\begin{array}{l}4.439 * * * \\
(1.65)\end{array}$ & $\begin{array}{l}4.179 * * \\
(1.77)\end{array}$ & $\begin{array}{l}-79.175^{* * *} \\
(18.12)\end{array}$ & $\begin{array}{l}4.327^{* * * *} \\
(1.54)\end{array}$ & $\begin{array}{l}4.434^{* *} \\
(2.066)\end{array}$ \\
\hline Media & $\begin{array}{l}1.842^{* * * *} \\
(0.33)\end{array}$ & $\begin{array}{l}2.128^{* * *} \\
(0.40)\end{array}$ & $\begin{array}{l}-0.136^{* *} \\
(0.06)\end{array}$ & $\begin{array}{l}-0.135^{* *} \\
(0.06)\end{array}$ & $\begin{array}{l}2.036^{* * *} \\
(0.46)\end{array}$ & $\begin{array}{l}-0.149 * * \\
(0.05)\end{array}$ & $\begin{array}{l}-0.150 * \\
(0.075)\end{array}$ \\
\hline Weak & $\begin{array}{l}0.855^{* *} \\
(0.33)\end{array}$ & $\begin{array}{l}1.149 * * * \\
(0.43)\end{array}$ & $\begin{array}{l}-0.299 * * * \\
(0.02)\end{array}$ & $\begin{array}{c}-0.057 \\
(0.07)\end{array}$ & $\begin{array}{l}33.880 * * \\
(16.41)\end{array}$ & $\begin{array}{l}-0.306^{* * * *} \\
(0.02)\end{array}$ & $\begin{array}{l}-0.295^{* * *} \\
(0.021)\end{array}$ \\
\hline Credit-to-deposit ratio & $\begin{array}{l}1.139 \\
(0.76)\end{array}$ & $\begin{array}{l}0.870 \\
(0.63)\end{array}$ & $\begin{array}{l}-0.064 \\
(0.06)\end{array}$ & $\begin{array}{l}-0.079 \\
(0.07)\end{array}$ & $\begin{array}{l}0.738 \\
(0.83)\end{array}$ & $\begin{array}{l}-0.047 \\
(0.05)\end{array}$ & $\begin{array}{l}-0.070 \\
(0.06)\end{array}$ \\
\hline Capital ratio & $\begin{array}{l}0.362 \\
(3.71)\end{array}$ & $\begin{array}{l}2.052 \\
(3.41)\end{array}$ & $\begin{array}{l}0.049 \\
(0.21)\end{array}$ & $\begin{array}{l}0.177 \\
(0.27)\end{array}$ & $\begin{array}{l}-1.556 \\
(5.10)\end{array}$ & $\begin{array}{l}0.244 \\
(0.25)\end{array}$ & $\begin{array}{l}0.275 \\
(0.282)\end{array}$ \\
\hline Correspondent relationship & $\begin{array}{l}-0.255 \\
(0.35)\end{array}$ & $\begin{array}{c}-0.445 \\
(0.42)\end{array}$ & $\begin{array}{l}-0.011 \\
(0.02)\end{array}$ & $\begin{array}{l}-0.008 \\
(0.02)\end{array}$ & $\begin{array}{l}-0.186 \\
(0.53)\end{array}$ & $\begin{array}{l}-0.007 \\
(0.01)\end{array}$ & $\begin{array}{l}0.002 \\
(0.020)\end{array}$ \\
\hline Distance & $\begin{array}{l}0.003^{* *} \\
(0.00)\end{array}$ & $\begin{array}{l}0.003 * \\
(0.002)\end{array}$ & & & $\begin{array}{l}0.002 \\
(0.002)\end{array}$ & & \\
\hline \# of depositors & & $\begin{array}{l}0.92 \\
(0.80)\end{array}$ & $\begin{array}{l}-0.17 * * \\
(0.077)\end{array}$ & $\begin{array}{c}-0.19 * * \\
(0.082)\end{array}$ & $\begin{array}{l}0.000 \\
(0.00)\end{array}$ & $\begin{array}{l}-0.13^{* *} \\
(0.06)\end{array}$ & $\begin{array}{l}-0.15^{* *} \\
(0.06)\end{array}$ \\
\hline Interbank borrowing & & & $\begin{array}{l}-0.615 \\
(0.45)\end{array}$ & $\begin{array}{l}-0.423 \\
(0.41)\end{array}$ & $\begin{array}{l}6.916 \\
(6.08)\end{array}$ & $\begin{array}{l}-0.117 \\
(0.35)\end{array}$ & \\
\hline Interbank borrowing $\mathrm{x}$ Exposure & & & & & $\begin{array}{l}812.94 * * * \\
(299.35)\end{array}$ & $\begin{array}{l}-76.48^{* * *} \\
(18.04)\end{array}$ & \\
\hline Capital ratio x Exposure & $\begin{array}{l}-0.392^{* * * *} \\
(0.111)\end{array}$ & & & & $\begin{array}{l}-0.569 * * \\
(0.27)\end{array}$ & $\begin{array}{l}0.020 \\
(0.01)\end{array}$ & $\begin{array}{l}0.027^{*} \\
(0.015)\end{array}$ \\
\hline \# of depositors x Exposure & & $\begin{array}{l}0.325 * * \\
(0.163)\end{array}$ & & & $\begin{array}{l}0.523^{* *} \\
(0.22)\end{array}$ & $\begin{array}{l}-0.037 * * * \\
(0.01)\end{array}$ & $\begin{array}{l}-0.038 * * * \\
(0.014)\end{array}$ \\
\hline Weak x Exposure & & & $\begin{array}{l}-0.152^{* * *} \\
(0.01)\end{array}$ & & $\begin{array}{l}15.403^{* *} \\
(7.62)\end{array}$ & $\begin{array}{l}-0.148^{* * *} \\
(0.01)\end{array}$ & $\begin{array}{l}-0.150 * * * \\
(0.01)\end{array}$ \\
\hline Size x Exposure & & & & $\begin{array}{l}0.019 \\
(0.01) \\
\end{array}$ & $\begin{array}{l}-0.343 \\
(0.23) \\
\end{array}$ & $\begin{array}{l}0.058^{* * *} \\
(0.01)\end{array}$ & $\begin{array}{l}0.057 * * * \\
(0.01)\end{array}$ \\
\hline District controls & no & no & yes & yes & no & yes & yes \\
\hline Number of banks & 142 & 121 & 104 & 104 & 104 & 104 & 87 \\
\hline Adj./pseudo $R$-squared & 0.240 & 0.287 & 0.471 & 0.339 & 0.445 & 0.576 & 0.550 \\
\hline
\end{tabular}




\section{Table 10}

\section{The effect of exposure on loan growth and profitability}

This table presents results of OLS regressions where the dependent variables are Loan growth, Credit-deposit ratio growth, and Profit growth. Loan growth is defined as $\log \left(\mathrm{L}_{\mathrm{t}} / \mathrm{L}_{\mathrm{t}-1}\right)$ where $\mathrm{L}_{\mathrm{t}}$ is the level of loans as on December 31, 2001, and $\mathrm{L}_{\mathrm{t}-1}$ is the level of loans as on March 31, 2001. Credit deposit ratio growth is defined as $\log \left(\mathrm{CD}_{\mathrm{t}} / \mathrm{CD}_{\mathrm{t}-1}\right)$ where $\mathrm{CD}_{\mathrm{t}}$ is the creditdeposit ratio as on December 31, 2001, and $\mathrm{CD}_{\mathrm{t}-1}$ is the credit-deposit ratio as on March 31, 2001. Profit growth is $\log \left(\mathrm{P}_{\mathrm{t}} / \mathrm{P}_{\mathrm{t}-}\right.$ ${ }_{1}$ ) where $P_{t}$ is the level of profits as on March 31, 2002, and $P_{t-1}$ is the level of profits as on March 31, 2001. Exposure is the credit outstanding of a bank with the failed bank divided by its total assets as on March 13, 2001. All the independent variables are described in the Appendix. All balance sheet variables are measured as on March 31, 2001, unless otherwise stated. Heteroskedasticity-robust standard errors are in parentheses. Unless otherwise stated, regressions are estimated with constants, but the coefficients are not reported. *, **, *** denote statistical significance at the $10 \%, 5 \%$, and $1 \%$ levels, respectively.

\begin{tabular}{|c|c|c|c|c|c|}
\hline & $\begin{array}{l}\text { Loan } \\
\text { growth }\end{array}$ & $\begin{array}{l}\text { Loan } \\
\text { growth }\end{array}$ & $\begin{array}{l}\text { Credit- } \\
\text { deposit ratio } \\
\text { growth }\end{array}$ & $\begin{array}{l}\text { Profit } \\
\text { growth }\end{array}$ & $\begin{array}{l}\text { Profit } \\
\text { growth }\end{array}$ \\
\hline & $(1)$ & $(2)$ & (3) & (4) & $(5)$ \\
\hline Exposure & $\begin{array}{l}-0.503^{* *} \\
(0.167)\end{array}$ & $\begin{array}{l}-0.445^{* *} \\
(0.215)\end{array}$ & $\begin{array}{c}0.191 \\
(0.308)\end{array}$ & $\begin{array}{l}-3.755^{* * *} \\
(0.778)\end{array}$ & $\begin{array}{c}-3.040 * * * \\
(0.805)\end{array}$ \\
\hline Return on assets & $\begin{array}{l}0.714 \\
(2.744)\end{array}$ & $\begin{array}{l}-0.108 \\
(1.593)\end{array}$ & $\begin{array}{l}-4.402 * * \\
(2.052)\end{array}$ & & \\
\hline Capital ratio & $\begin{array}{l}-0.115 \\
(0.422)\end{array}$ & $\begin{array}{r}-0.014 \\
(0.333)\end{array}$ & $\begin{array}{l}0.213 \\
(0.318)\end{array}$ & $\begin{array}{l}-0.682 \\
(1.157)\end{array}$ & $\begin{array}{l}-0.351 \\
(1.150)\end{array}$ \\
\hline Credit-to-deposit ratio & $\begin{array}{l}-0.040 \\
(0.078)\end{array}$ & $\begin{array}{r}-0.010 \\
(0.102)\end{array}$ & & $\begin{array}{l}-0.969 * * * \\
(0.302)\end{array}$ & $\begin{array}{c}-0.977 * * * \\
(0.304)\end{array}$ \\
\hline Size & $\begin{array}{l}0.016 \\
(0.019)\end{array}$ & $\begin{array}{l}0.006 \\
(0.018)\end{array}$ & $\begin{array}{l}0.014 \\
(0.016)\end{array}$ & $\begin{array}{l}-0.023 \\
(0.065)\end{array}$ & $\begin{array}{l}-0.007 \\
(0.063)\end{array}$ \\
\hline Media & $\begin{array}{l}-0.124 * * \\
(0.022)\end{array}$ & $\begin{array}{l}-0.131^{* *} \\
(0.058)\end{array}$ & $\begin{array}{c}0.051 \\
(0.059)\end{array}$ & $\begin{array}{l}-0.204 \\
(0.188)\end{array}$ & $\begin{array}{l}-0.180 \\
(0.230)\end{array}$ \\
\hline Correspondent relationship & $\begin{array}{l}-0.004 \\
(0.018)\end{array}$ & $\begin{array}{l}0.014 \\
(0.029)\end{array}$ & $\begin{array}{l}0.003 \\
(0.033)\end{array}$ & $\begin{array}{l}0.095 \\
(0.080)\end{array}$ & $\begin{array}{l}0.140 * \\
(0.074)\end{array}$ \\
\hline Distance & $\begin{array}{c}0.0006^{* * *} \\
(0.0001)\end{array}$ & & & $\begin{array}{l}0.000 \\
(0.000)\end{array}$ & \\
\hline Weak & & & & $\begin{array}{l}-0.389 * * \\
(0.193)\end{array}$ & $\begin{array}{c}-0.385^{*} \\
(0.222)\end{array}$ \\
\hline District controls & no & yes & yes & no & yes \\
\hline Number of banks & 129 & 129 & 129 & 128 & 128 \\
\hline Adj./pseudo $R$-squared & 0.271 & 0.232 & 0.147 & 0.230 & 0.323 \\
\hline
\end{tabular}




\section{Table 11 \\ The real effects of interbank contagion}

This table presents results of OLS regressions where the dependent variables are Deposit growth, Loan growth, Future loan growth, and Profit growth. Deposit growth is $\log \left(\mathrm{D}_{\mathrm{t}} / \mathrm{D}_{\mathrm{t}-1}\right)$ where $\mathrm{D}_{\mathrm{t}}$ is the level of deposits as on December 31, 2001, and $\mathrm{D}_{\mathrm{t}-1}$ is the level of deposits as on March 31, 2001. Loan growth is defined as $\log \left(\mathrm{L}_{t} / \mathrm{L}_{t-1}\right)$ where $\mathrm{L}_{t}$ is the level of loans as on December 31, 2001, and $\mathrm{L}_{t-1}$ is the level of loans as on March 31, 2001. Future loan growth is defined as $\log \left(\mathrm{L}_{t} / \mathrm{L}_{\mathrm{t}-1}\right)$ where $\mathrm{L}_{\mathrm{t}}$ is the level of loans as on March 31, 2002, and $\mathrm{L}_{\mathrm{t}-}$ ${ }_{1}$ is the level of loans as on December 31, 2001. Profit growth is $\log \left(\mathrm{P}_{\mathrm{t}} / \mathrm{P}_{\mathrm{t}-1}\right)$ where $\mathrm{P}_{\mathrm{t}}$ is the level of profits as on March 31, 2002, and $\mathrm{P}_{\mathrm{t}-}$ ${ }_{1}$ is the level of profits as on March 31, 2001. Dummy Low exposure is equal to 1 if exposure is lower than or equal to 3.83\%, and 0 otherwise. Avg district exposure of other banks is defined as the average exposure of other banks in the same district. \# of other banks is the number of other banks in the same district. All the independent variables are described in the Appendix. All balance sheet variables are measured as on March 31, 2001, unless otherwise stated. Heteroskedasticity-robust standard errors clustered at district level are reported in parentheses. Unless otherwise stated, regressions are estimated with constants, but the coefficients are not reported. *, **, *** denote statistical significance at the $10 \%, 5 \%$, and $1 \%$ levels, respectively.

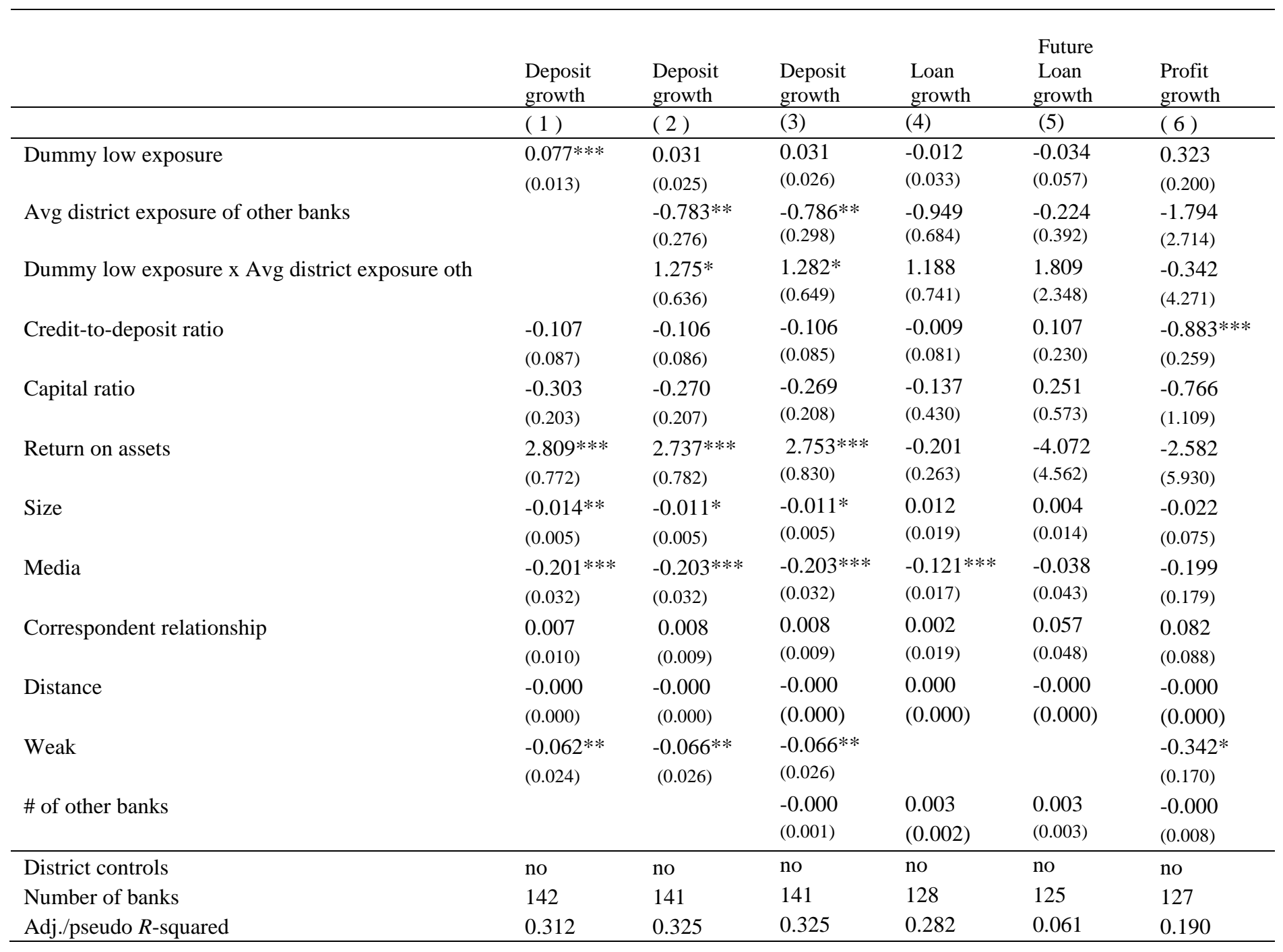


Figure 1 presents the timeline of events and data.

Figure 1

Timeline of events and dat a

EVENTS

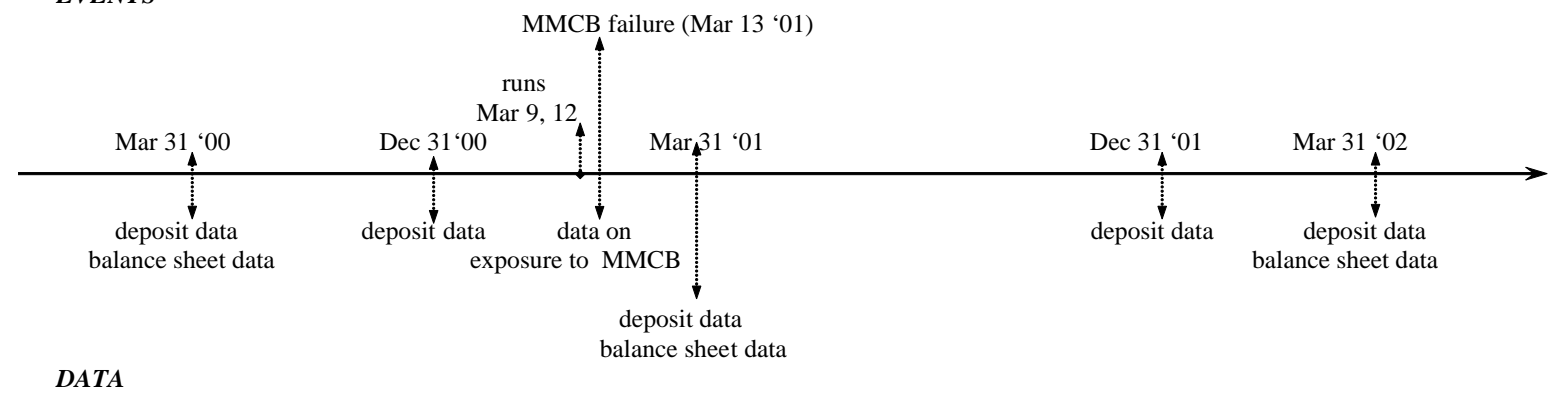


Figure 2A presents the relationship between different thresholds of exposure with deposit growth and large deposit withdrawals. Figure 2B reports the same relationship in the period before the failure of the large bank. Deposit growth is $\log \left(\mathrm{D}_{\mathrm{t}} / \mathrm{D}_{\mathrm{t}-1}\right)$ where $\mathrm{D}_{\mathrm{t}}$ is the level of deposits as on December 31,2001 , and $\mathrm{D}_{\mathrm{t}-1}$ is the level of deposits as on March 31, 2001. Large deposit withdrawals is a dummy variable that takes the value of 1 if deposit growth is lower than or equal to $-12.75 \%$ (which implies that $20 \%$ of the observations exhibit large deposit withdrawals). Exposure is the credit outstanding of a bank with the failed bank divided by its total assets as on March 13, 2001. Dummy high exposure is a dummy variable that takes the value of 1 if exposure is higher than or equal to $9.21 \%$ (average plus one standard deviation of exposure if exposure is positive). Dummy medium exposure is a dummy variable that takes the value of 1 if exposure is higher than or equal to $3.83 \%$ (average of exposure if exposure is positive) and lower than $9.21 \%$. Dummy low exposure is a dummy variable that takes the value of 1 if exposure is lower than $3.83 \%$ and higher than $0 \%$. Dummy zero exposure is a dummy variable that takes the value of 1 if exposure is equal to $0 \%$. Dummy variables take the value of zero otherwise.

Figure 2a

\section{Relationship between deposit withdrawals and exposure after failure of large bank}

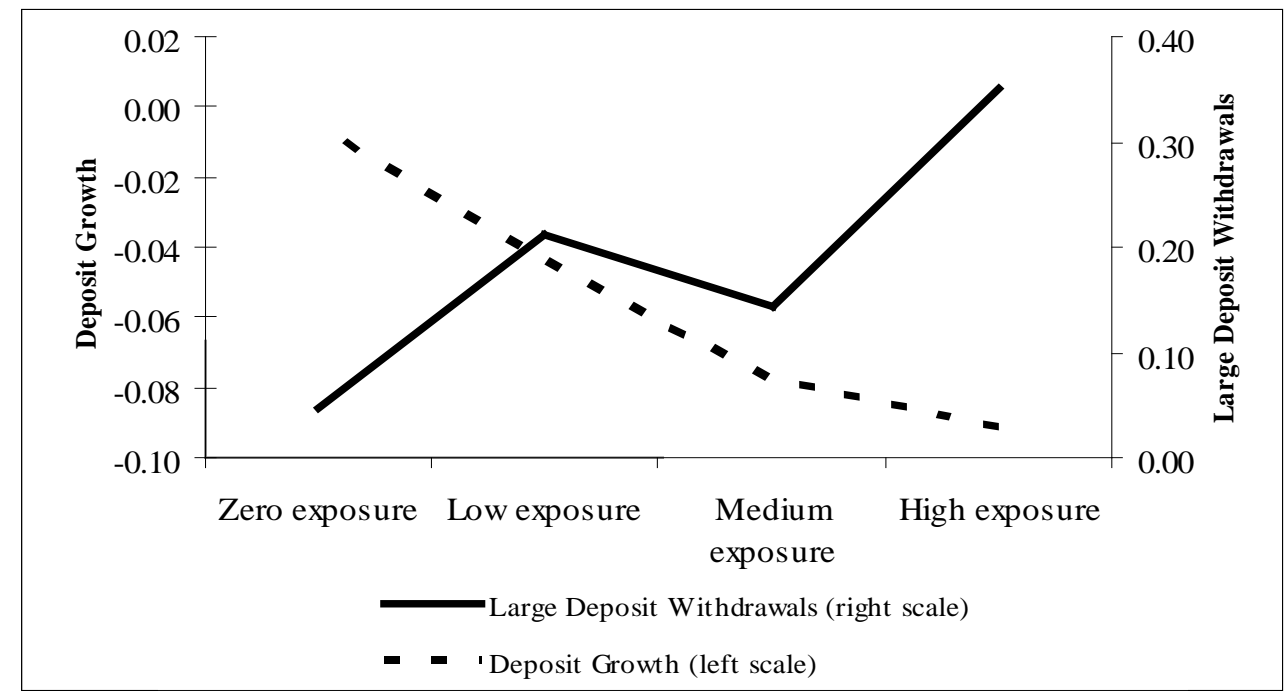

Figure 2b

Relationship between deposit withdrawals and exposure before failure of large bank

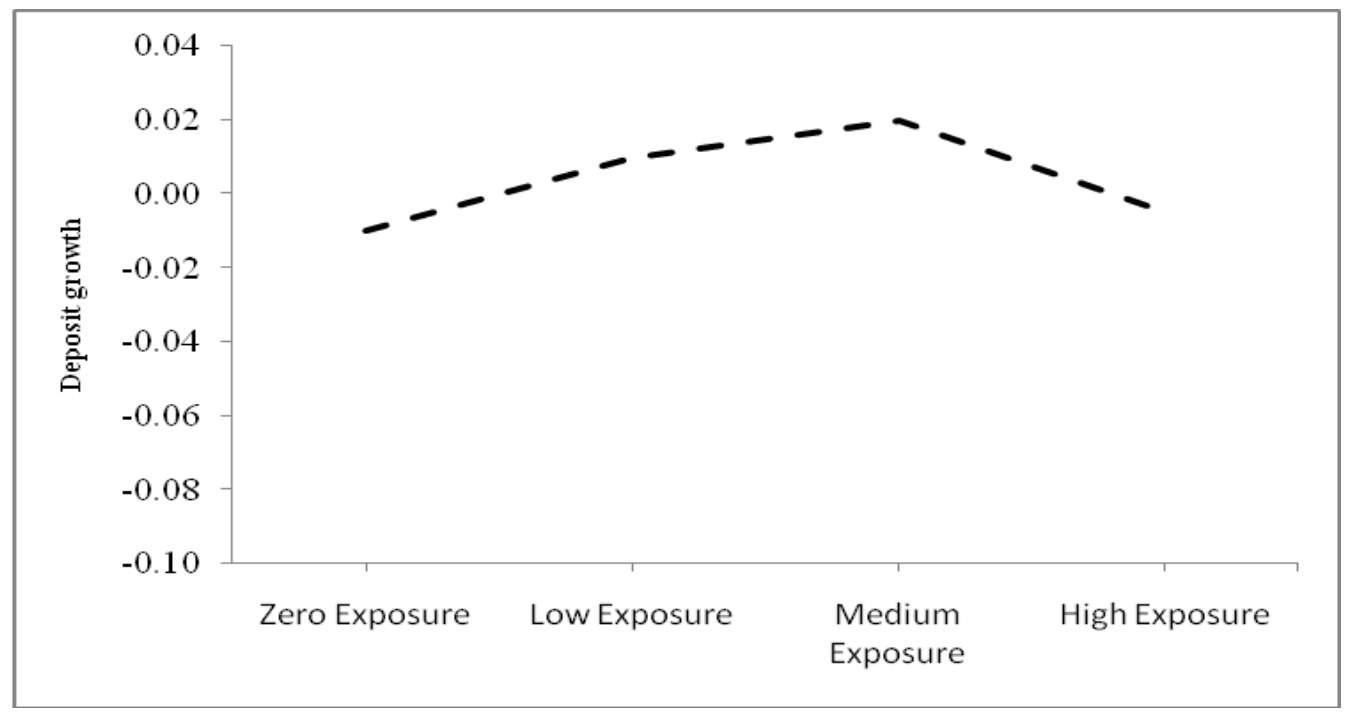

